\title{
Omics for Bioprospecting and Drug Discovery from Bacteria and Microalgae
}

\author{
Reuben Maghembe 1,2,3, Donath Damian ${ }^{1}$ (D), Abdalah Makaranga 2,4 (D), \\ Stephen Samwel Nyandoro ${ }^{5}$, Sylvester Leonard Lyantagaye ${ }^{1,6}$, Souvik Kusari ${ }^{7, * \mathbb{D}}$ and \\ Rajni Hatti-Kaul ${ }^{3, *}$
}

1 Department of Molecular Biology and Biotechnology, College of Natural and Applied Sciences, University of Dar es Salaam, P.O. Box 25179, Dar es Salaam, Tanzania; rmaghembe@gmail.com (R.M.); donath.damian@yahoo.com (D.D.); slyantagaye@udsm.ac.tz (S.L.L.)

2 Department of Biological and Marine Sciences, Marian University College, P.O. Box 47, Bagamoyo, Tanzania; abdalahmakaranga@gmail.com

3 Division of Biotechnology, Department of Chemistry, Center for Chemistry and Chemical Engineering, Lund University, Box 124, 22100 Lund, Sweden

4 International Center for Genetic Engineering and Biotechnology (ICGEB), Omics of Algae Group, Aruna Asaf Ali Marg, New Delhi 110067, India

5 Chemistry Department, College of Natural and Applied Sciences, University of Dar es Salaam, P.O. Box 35061, Dar es Salaam, Tanzania; nyandoro@udsm.ac.tz

6 Department of Biochemistry, Mbeya College of Health and Allied Sciences, University of Dar es Salaam, P.O. Box 608, Mbeya, Tanzania

7 Institute of Environmental Research (INFU), Department of Chemistry and Chemical Biology, Technische Universität Dortmund, Otto-Hahn-Straße 6, 44221 Dortmund, Germany

* Correspondence: souvik.kusari@tu-dortmund.de (S.K.); rajni.hatti-kaul@biotek.lu.se (R.H.-K.); Tel.: +49-2317554086 (S.K.); +46-462224840 (R.H.-K.)

Received: 9 March 2020; Accepted: 29 April 2020; Published: 4 May 2020

Abstract: "Omics" represent a combinatorial approach to high-throughput analysis of biological entities for various purposes. It broadly encompasses genomics, transcriptomics, proteomics, lipidomics, and metabolomics. Bacteria and microalgae exhibit a wide range of genetic, biochemical and concomitantly, physiological variations owing to their exposure to biotic and abiotic dynamics in their ecosystem conditions. Consequently, optimal conditions for adequate growth and production of useful bacterial or microalgal metabolites are critically unpredictable. Traditional methods employ microbe isolation and 'blind'-culture optimization with numerous chemical analyses making the bioprospecting process laborious, strenuous, and costly. Advances in the next generation sequencing (NGS) technologies have offered a platform for the pan-genomic analysis of microbes from community and strain downstream to the gene level. Changing conditions in nature or laboratory accompany epigenetic modulation, variation in gene expression, and subsequent biochemical profiles defining an organism's inherent metabolic repertoire. Proteome and metabolome analysis could further our understanding of the molecular and biochemical attributes of the microbes under research. This review provides an overview of recent studies that have employed omics as a robust, broad-spectrum approach for screening bacteria and microalgae to exploit their potential as sources of drug leads by focusing on their genomes, secondary metabolite biosynthetic pathway genes, transcriptomes, and metabolomes. We also highlight how recent studies have combined molecular biology with analytical chemistry methods, which further underscore the need for advances in bioinformatics and chemoinformatics as vital instruments in the discovery of novel bacterial and microalgal strains as well as new drug leads.

Keywords: omics; drug discovery; bacteria; microalgae; biosynthetic gene clusters 


\section{Introduction}

Throughout history, bioprospecting for bioactive molecules has been focused on the ability of an individual organism to produce compounds of interest under natural or localized optimal conditions. This approach has been traditionally practiced apparently due to historical plant-based drug discovery using ethnobotanical information about biodiversity and its nature [1-3]. On the other hand, drug discovery from microorganisms has been carried out by relying on cultivability of the target microbes [4-6]. On a traditional basis, microorganisms have been transferred from their natural habitats to laboratory plates and bioreactors with various efforts to mimic the natural environment in a bid to produce compounds of interest (Figure 1). Challenges arising from this practice have mounted enormous interest in understanding the dynamics of laboratory conditions and natural environmental parameters concerning metabolites produced by organisms of interest. The following questions are critical to the bioprospecting endeavor:

(1) What factors determine the organism's ability to express target molecules under natural or laboratory conditions?

(2) What factors could promote de novo biosynthesis of a metabolite of interest?

(3) How accurate are the methods applied in screening the microorganism bearing potential for compounds of interest?

(4) What approaches can enhance the likelihood of encountering a compound of interest from the strain under research?

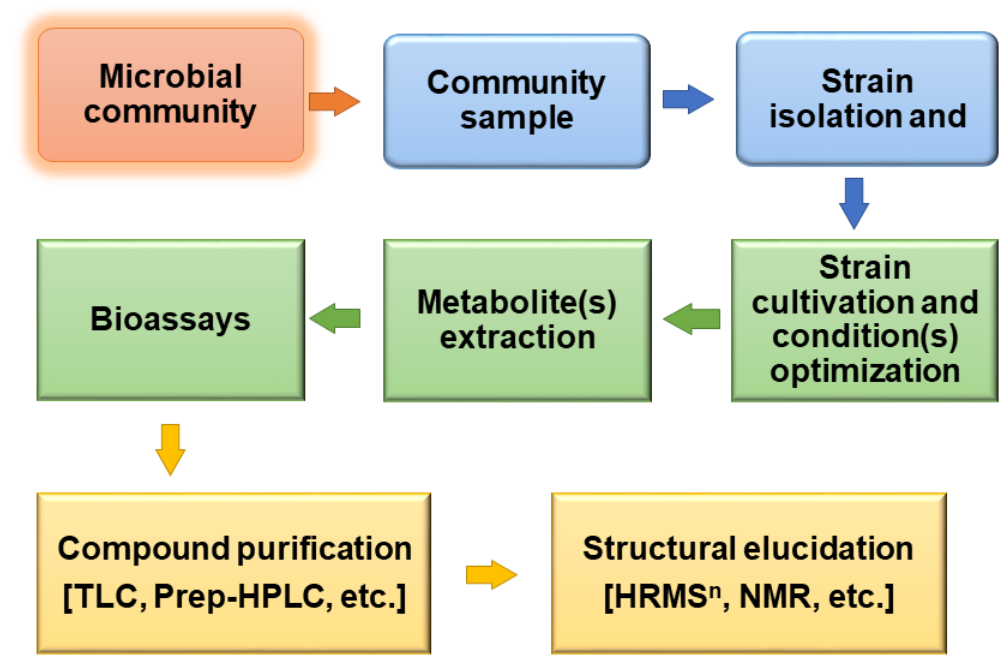

Figure 1. A typical workflow for conventional bioprospecting and drug discovery.

Organisms produce compounds with different biological activities in response to biotic and abiotic stresses such as the emergence of predators, competition for resources, communicatory signals, and variations in physicochemical conditions of their ecosystems [7-10]. In light of such factors, each microbe has to be obtained, selective culture media designed, culture conditions optimized for eventual cultivation of the targeted microbe, and ultimately isolation and characterization of the metabolites of interest.

However, during sampling, not all useful microbes may be readily accessible, and since some are typically present in low abundance or distribution, the sampling process might overlook a reasonable number of such vital species. Besides, the process of cultivating microbes in the laboratory faces multiple challenges such that some microorganisms are not readily cultivable [6,11]. Even under laboratory cultivation, it might be challenging to infer whether the cultivated species has potential for the compound of interest unless chemical analysis follows a number of cultivation and optimization procedures. Furthermore, with chemical analysis, if one or more compounds are not detected (e.g., below the limit of detection), it is hard to precisely establish the cause of a compound missing in the 
experimental sample. These challenges underscore the need for improved preliminary screening of the microbes before wasting resources and time for culture and further analysis.

Omics, entailing genomics, metagenomics, transcriptomics, proteomics, lipidomics, glycomics, and metabolomics, represents a robust combinatorial approach towards discoveries of several biological entities that could not be discovered for the past several decades due to limited coverage and resolution of the conventional methods $[12,13]$. While genomics recovers information from individual whole genomes, metagenomics resolves genomes of communities of microorganisms and viruses $[13,14]$. On the other hand, transcriptomics focuses on the expression pattern of genomes via recovery of the whole RNA by what is known as transcriptome shotgun sequencing or RNA sequencing (RNA-Seq) $[15,16]$. Proteomics, lipidomics, and glycomics involve protein (proteomes), lipid (lipidome), and carbohydrate (glycome) profiles, respectively, whereas metabolomics focuses on the pattern of metabolic pathways and their natural products. The combined effect of these methods guarantees high-throughput screening and discovery of novel bio-entities with insight into their phylogenetic diversities, abundance, distribution, and ecological function of each community member, including those that could hardly be cultivable earlier [17-19] (Figure 2). Algal multi-omic approaches are increasingly emerging with a variety of possible optimizations towards enhanced production and elucidation of biofuel biosynthetic pathways, in addition to other applications in the biotechnology industry [20]. On the other hand, bacterial omics approaches present a promising avenue to curtail the emergence of bacterial multidrug resistance through the integration of genomic mapping of diverse drug-resistance gene clusters, transcriptome pathways as well as alternative molecular targets [21].

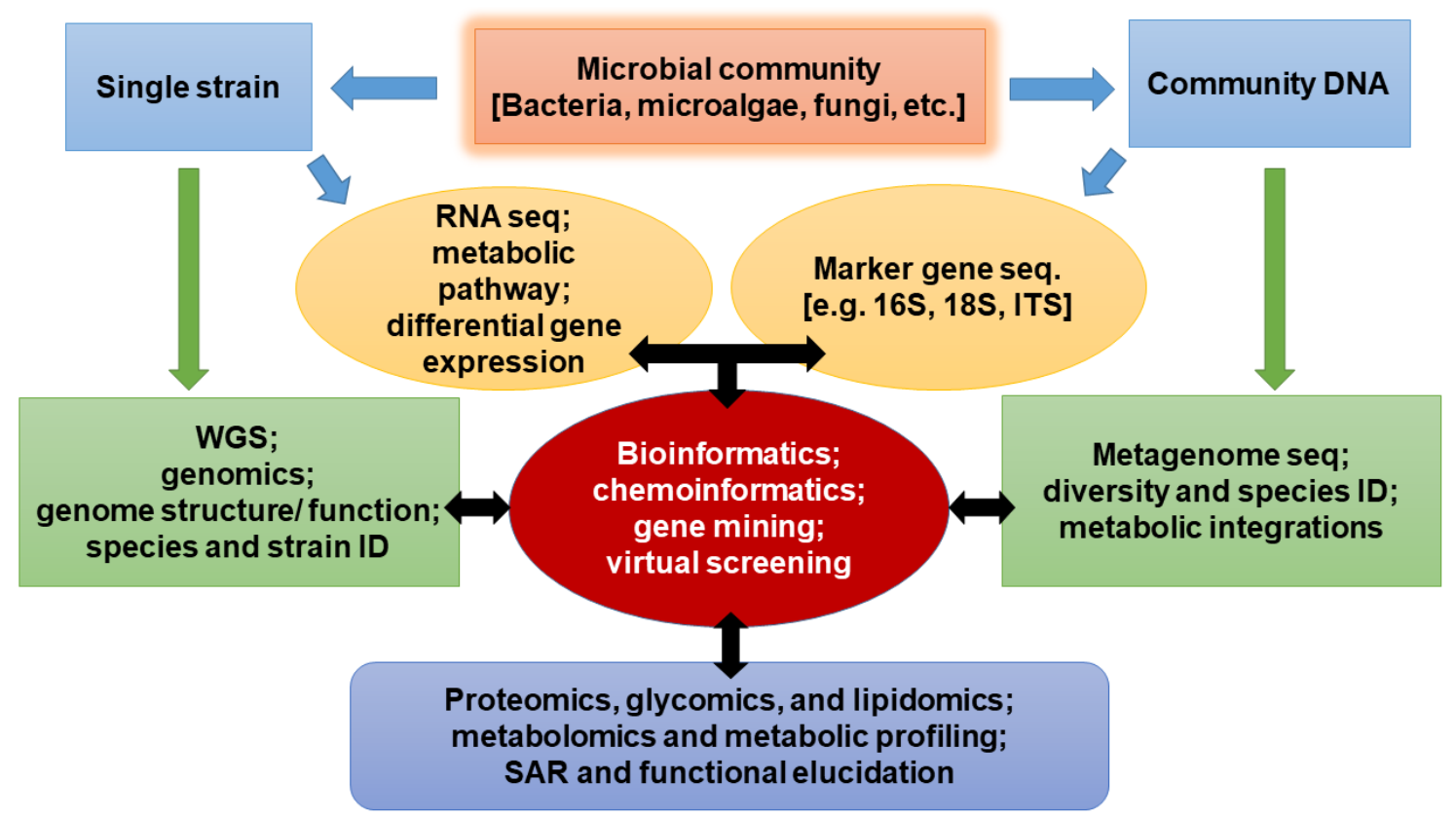

Figure 2. A typical workflow for omics, integrating molecular, chemical, and computational science to elucidate the potential of microorganisms and molecules for therapeutics.

Bacteria are adapted to a wide range of habitats ranging from soil, fresh and salt waters to hot springs. Microalgae comprise a microscopic group of photosynthetic forms of the phytoplankton community, which ecologically sustains the life of most groups of aquatic biodiversity. Both terrestrial and aquatic ecosystems encompass prokaryotic microorganisms, including actinobacteria (e.g., Streptomyces spp.) and blue-green algae, the cyanobacteria (e.g., Arthrospira spp.) as well as the eukaryotic forms of microalgae such as diatoms (Bacillariophyceae), green algae (Chlorophyceae), and golden algae (Chrysophyceae) [21]. These communities are diverse and highly influenced by ecological conditions, which trigger genomic transformations, and consequently, biochemical and physiological 
diversities. In turn, these eco-biochemical changes promote diversification of forms and levels of metabolites produced by different strains under similar or different ecological conditions $[7,22,23]$.<smiles>COc1ccc2[nH]c(SCc3ccc(C)cc3)nc2c1</smiles>

(a)<smiles>COc1ccc2[nH]c(=[SH]Cc3ccc(Cl)cc3)[nH]c2c1</smiles>

(b)<smiles>CCCCC/C=C\C/C=C\C/C=C\CCCCC(=O)O</smiles>

(c)<smiles>CCCCCCCCCCCCCC(=O)OC[C@H](COC1CCC2(CS(=O)(=O)O)CC(O)C(C1)C2O)OC(=O)CCCCCCCCCCC</smiles>

(d)

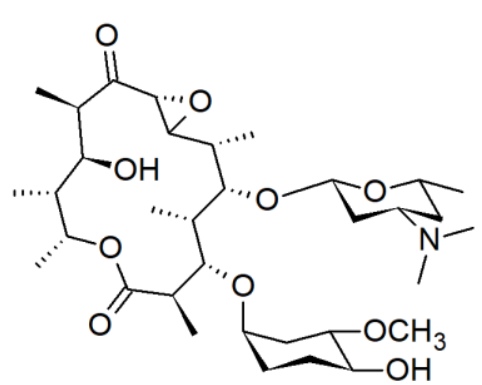

(e)<smiles>C/C=C1C(=C/c2[nH]c(/C=C3\N=C(/C=C4/CC(=O)C(CC)=C4C)C(C)=C3CCC(=O)O)c(CCC(=O)O)c2C)\NC(=O)C\1C</smiles>

(f)<smiles>Cc1cncc(Cc2c[nH]c3ccccc23)n1</smiles>

(g)

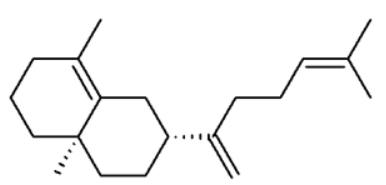

(j)<smiles>OCC(O)C(O)Cc1cncc(-c2ccco2)n1</smiles>

(h)<smiles>C[C@H]1CCC[C@]2(C)CCCC[C@@]12O</smiles>

(i)<smiles>CC(C)=CCC/C(C)=C1\C=C2[C@H](C)CCC[C@]2(C)CC1</smiles>

(k)

Figure 3. Structures of selected bioactive metabolites from bacteria and microalgae: (a) 5-methoxy-2-[(4-methylbenzyl)sulfanyl]-1H-benzimidazole, a potent antibiofilm compound; (b) 2-[(4-chloro-benzyl)thio]-5-methoxy- $1 H$-benzimidazole, an antibiofilm compound; (c) $\gamma$-linolenic acid, a fatty acid with multiple bioactivities. i.e., neuromodulatory, antimicrobial activity etc.; (d) sulfoquinovosyl diacyl glycerol, an antiviral sulfo-glycolipid; (e) oleandomycin; an antibacterial molecule; (f) C-phycocyanin, a pigment with pluripotecy; antiviral, anticancer, antioxidant activities, etc.; (g) 3-((6-methylpyrazin-2-yl)methyl)-1 $H$-indole, an antibacterial alkaloid; (h) 2-(furan-2-yl)-6-(2,3,4-trihydroxybutyl)pyrazine, an antiviral alkaloid; (i) geosmin, a biomarker for several soil actinomycetes; (j) clavulatriene A; (k) clavulatriene B, antibacterial and anticancer lead compounds $(\mathrm{j}, \mathrm{k})$. 
Bacteria and microalgae produce a plethora of compounds, generally including fatty acids, lipopeptides, sulfolipids, cyclic peptides, terpenoids, saccharides, alkaloids, flavonoids, pigments, macrolides, and aminoglycosides, as well as well-established therapeutic agents such as tetracycline, bialaphos, clavulanic acid, and rapamycin [23-25] among many others [26-28] (selected examples in Figure 3). Although microalgae and eukaryotic organisms typically produce terpenes, evidence suggests that bacteria produce a considerable number of terpenomes with intriguing bioactive potential [29]. Examples of bacterial terpenoids include geosmin, 2-methylisoborneol, as well as clavulatriene A and B [29] as antibacterial and anticancer candidates. Most of these metabolites possess significant bioactivities against infectious agents, metabolic diseases, inflammatory diseases, cancer, and neurological conditions [28-32]. Recently, microalgal compounds have been reported to have antibiofilm activity $[33,34]$, promising a scaffold for countering drug resistance. The conundrum of identifying microorganisms among members in a versatile community has been abridged by the advances in molecular biology with the omics approach. In recent years, interest in bioprospecting of biologically active metabolites from extremophiles has increased [34,35]. The molecular adaptations of extremophiles to their environment are of interest in research as their genomes are hallmarked by stability and production of somewhat adapted peptides with bioactivities such as antibacterial, anticancer, and antiviral activities [31,36]. Optimization of appropriate cultivation conditions for extremophiles is hampered by the microbes' preference for conditions that are complex to establish under laboratory settings. For example, thermophilic bacteria such as Geobacillus spp. and Aeribacillus spp. dwelling in hot springs are difficult to cultivate albeit their intriguing genomes render them useful for bioprospecting [35].

\section{Metabarcoding and Metagenomics in Discovery of Strains of Interest}

\subsection{Metabarcoding}

Metabarcoding targets a specific DNA region in the entire community as a marker for diversity and phylogenetic mapping of the microbes constituting the community in question [36,37]. Commonly used marker regions include the small subunit (SSU) ribosomal RNA genes $16 \mathrm{~S}$ and $18 \mathrm{~S}$ for prokaryotic and eukaryotic DNA, respectively [38,39]. 16S is perhaps the most widely used molecular marker in studying microbiome diversities in a range of studies from the field to clinical laboratory settings [40-45]. Based on the V4-region target amplification, $16 \mathrm{~S}$ sequencing has been widely used in the taxonomic characterization of microbiomes under different ecosystem conditions [40-43]. In bioprospecting of potential bacteria, $16 \mathrm{~S}$ metabarcoding has been used in the identification of Arthrospira spp, Nostoc spp, Streptomyces spp., and Geobacillus spp. [45-47], to mention a few. Another marker for metabarcoding is the internal transcribed spacer (ITS), which in prokaryotes is located between $16 \mathrm{~S}$ and 23S RNA genes and is used as a target marker for intragenomic variations [46]. In eukaryotes, there are two types of ITS markers; ITS1 and ITS2. While ITS1 is predominantly positioned between 18S and 5.8S-rRNA, ITS2 resides between 5.8S-rRNA and $26 \mathrm{~S}$ regions (or between $18 \mathrm{~S}$ and $28 \mathrm{~S}$ in case of opisthokonts) [47]. Recently, these markers have been used to place up to 32 microalgal strains from culture to different taxa and screening for their ice nucleation active (INA) compounds [48]. ITS can be combined with other markers for better resolution. In a recent barcoding study [49], ITS1 and ITS2 of the nuclear rRNA gene (nuITS1 and nuITS2), combined with ribulose bisphosphate carboxylase large $(r b c l)$ subunit gene, displayed dominant resolution in the screening of freshwater green microalgae. $R b c l$ has also been used in the identification of the cyanobacterium Arthrospira and green microalga Dunaliella [50]. In a study by Duong et al. [51], 36 strains of green microalgae were identified by $18 \mathrm{~S}$ rRNA sequencing and were clustered into their respective genera, which guided further analysis of relevant protein and lipid profiles. Metabarcoding, therefore, offers an overview of community structure, composition, diversity, and taxonomic positions of various groups within and between ecosystems [39,52]. The application of metabarcoding can simplify the identification and characterization of bacterial as well as microalgal communities with the potential for "bioproducts" in a preliminary snapshot. 
Although metabarcoding is a rapid and cost-effective method, it has considerably limited resolution and could hardly discriminate closely related species or strains. These challenges are based on its polymerase chain reaction (PCR) short length sequencing associated with guanine-cytosine (GC) content bias sequencing errors and the assignment of operational taxonomic units (OTUs) [15]. Notwithstanding some improvement in OTU picking, metabarcoding is relatively limited as far as the genus level [39,53-55]. Metabarcoding cannot establish the molecular involvement of each microbe in the ecosystem. By targeting only one portion of the metagenome, many genes are untapped; thus, their structures and functions in the community remain undeciphered. Considering the complexity of bacterial and microalgal communities, methods with broad coverage are necessary for a compelling description of the communities towards bioprospecting and drug discovery.

\subsection{Metagenomics}

Metagenomics involves deciphering information interlocked into the DNA of the entire microbial community in a target. Whole metagenome sequencing provides more detailed insights into community diversity and function than does metabarcoding. The generation of genome and protein databases represents a remarkable advance in microbial community characterization. High throughput sequencing of metagenomes is amenable to downstream analysis, giving insight into the entire community structure, comparative differences among ecosystems, precise descriptions of strains of biotechnological importance as well as novel genes [19,55]. Besides, this approach can further the analysis of genes involved in a number of biochemical pathways as well as interactions among the microbes in their natural environment or in bioreactors $[19,56,57]$. Through metagenomic screening, studies have managed to establish the molecular adaptation of the microorganisms to their environment, via cluster analysis and metabolic links $[11,19,58]$.

Recent next-generation sequencing (NGS) studies have established a broad scope of cyanobacterial genomes and their associated genes $[59,60]$. In the Cyanobacterial Knowledge Base (CKB), Peter and colleagues [58] published full genome sequences of 74 strains belonging to seven orders of the phylum Cyanobacteria. This database, together with other databases, like genome databases in the National Center for Biotechnology Information (NCBI), is crucial for structural and functional annotation of the cyanobacteria of interest [11]. Before the selection of microorganisms for culture and further screening, genome annotation could guide the selection of species or strains better suitable for the goal of the biotechnological study based on molecular blueprints unraveled from the database.

\section{Genomics and Metagenomics as Quick Guides to Discover Compounds of Interest}

In bioprospecting, it is interesting to elucidate the genes that code for enzymes that catalyze the biosynthetic pathways for the molecule(s) of interest. Before the development of nucleic acid sequencing technologies, conventional research was focused on targeting one to a few genes and characterizing their roles. This approach is usually based on traditional polymerase chain reaction (PCR) amplification of the target gene of interest and subjecting the sequences to first-generation sequencing, leaving the rest of the genome unexplored. Recent progress to NGS has rendered gene ontology more effective with the recovery of molecular interactions among members of a microbiome $[16,61]$ by annotations. NGS assures a better avenue for further cultivation of the microbe of interest under established conditions.

The current DNA sequencing technologies are considerably affordable, and it has become possible to recover full genomes of as many strains as possible. Studies demonstrate promising prospects of having thousands of microorganisms' genomes sequenced in the coming decades. A list of several full genomes available from NCBI databases and other sources is summarized in Table 1 . The availability of reference genomes simplifies the pursuit of novel strains through global and local alignment as well as structural and functional annotation of the genomes. Consequently, desirable strains for bioprospecting are rather readily identified. In addition to the rapid advancement of bioinformatics databases and 
platforms for analysis, the need to develop more user-friendly tools and to train more experts in the bioinformatics arena is critically high.

Table 1. Full genomes of selected bacteria and microalgal species available in databases.

\begin{tabular}{ccccc}
\hline Strain & Domain & Phylum & Genome Size & Reference \\
\hline Arthrospira platensis & Prokaryota & Cyanobacteria & $6.0 \mathrm{Mb}$ & {$[53]$} \\
Arthrospira platensis & Prokaryota & Cyanobacteria & $6.62 \mathrm{Mb}$ & {$[59]$} \\
Arthrospira maxima & Prokaryota & Cyanobacteria & $6.0 \mathrm{Mb}$ & $\mathrm{NCBI}$ \\
Chlorella sp. A99 & Eukaryota & Chlorophyta & 40.934 & $\mathrm{NCBI}$ \\
Chlorella vulgaris UTEX 395 & Eukaryota & Chlorophyta & $37.34 \mathrm{Mb}$ & {$[62]$} \\
Oscillatoria nigro-viridis PCC 7112 & Prokaryota & Cyanobacteria & $7.97 \mathrm{Mb}$ & {$[58]$} \\
Streptomyces lividans TK24 & Prokaryota & Actinobacteria & $8.345 \mathrm{Mbp}$ & {$[61]$} \\
Euzebya sp. DY32-46 & Prokaryota & Actinobacteria & $5.715 \mathrm{Mb}$ & {$[63]$} \\
Geobacillus sp. ZGt-1 & Prokaryota & Firmicutes & $3.7 \mathrm{Mb}$ & {$[37]$} \\
\hline
\end{tabular}

Whole-genome sequencing holds substantial potential for the identification of silent genes even in widely studied microbes like the actinobacteria of the genus Streptomyces; e.g., S. coelicolor or S. avermitilis [13]. Through bioinformatic genome annotation, the genomics approach could facilitate the identification of biosynthetic gene clusters (BGCs) and provide insights into the potential of various microbial strains for the compounds of interest [13].

\section{Transcriptomics}

Transcriptome analysis retrieves information about genes expressed under certain conditions. RNA sequencing may be categorized into two subgroups, viz. standard RNA seq and strand-specific RNA seq. The former mainly recovers information from coding sequences (CDS) and does not consider antisense strands. Strand-specific RNA seq is more powerful, giving comprehensive information regarding the expression of the gene. Antisense transcripts also have information mainly regarding regulatory functions (noncoding RNAs). Therefore, strand-specific RNA-seq could help to recover this vital information and thereby add knowledge about the transcriptome in question [17]. In bioprospecting, it is crucial to acquire an understanding of the expression pattern of genes encoding molecules of interest or enzymes catalyzing biosynthetic pathways of metabolites to be isolated. The main idea in conventional bioprospecting is that the desired compounds are produced as secondary metabolites, which, in essence, are a result of unusual deviations in environmental parameters. The challenging part is that compounds of interest are dependent upon the amount of biomass of the microbe grown under favorable growth conditions $[5,64,65]$. Furthermore, under standard cultivation conditions, some microorganisms tend to produce rather primary metabolites than secondary metabolites [66]. This underscores the need for alteration of the cultivation conditions many times, with concomitant screening for the metabolites, thus making the process of bioprospecting laborious and quite costly. The use of bioreactors and open ponds has shown considerable resolution for several of the scarcely-cultivable microalgae [65,67]. The alteration of one condition at a time could be coupled with RNA-Seq, giving rise to a broader view of the effect of culture conditions on the microbial genome under study. The differential expression pattern was observed with deep RNA-Seq of closely related halophilic strains of Salinibacter ruber when grown under varied culture conditions, whereby genes involved in environmental sensing were downregulated under pure independent culture [56]. Concomitantly, the same were upregulated during coculture, revealing an intimate interaction between the two strains [56]. In a recent study, pathway analysis of the actinobacteria Streptomyces davawensis revealed the involvement of the gene clusters containing creE and creD homologs in the biosynthesis of desferrioxamine derivatives under co-culture [68]. Eventually, every condition will contribute to understanding and aid in the selection of suitable culture conditions for the expression of target genes. This route enhances precision and guarantees better accuracy of bioprospecting by establishing the most decisive factors for the cultivation and production of compounds of interest. 
Moreover, transcriptome profiling could unravel the expression pattern of genes involved in drug resistance by pathogens challenged with drug candidates (e.g., crude extracts) against conventional drugs. In a study by Jones et al. [69], transcriptome profiling revealed global differential expression between Streptococcus aureus cells exposed to standard drugs and those exposed to crude extracts. Comparative analysis of the gene expression pattern could also reduce the rediscovery of already known drugs and prompt the discovery of novel therapeutic compounds [70]. Ramos et al. [21] coupled genomics with transcripts to come up with successful deconvolution of pathways related to multidrug resistance and as well as novel drug target candidates in Klebsiella pneumoniae. RNA-Seq is therefore amenable to high throughput characterization of samples towards the discovery of novel compounds. Transcriptome profiling could also facilitate the process of drug repositioning through a comparative analysis of gene expression patterns of pathogenic or pathological cells in response to standard drug against an alternative drug [70]. This involves testing the effects of the drug that is known to cure one disease, on another related or unrelated ailment, based on its ability to alter the transcriptome profile of a novel organism. By so doing, transcriptome profiling could rescue enormous amounts of resources invested in traditional approaches in a bid to discover novel drugs.

\subsection{Transcriptomics in the Discovery of Noncoding RNAs with a Metabolic Regulatory Role}

Strand-specific RNA Seq is a powerful transcriptomic approach to identify a myriad of RNA forms. Several noncoding RNAs (ncRNAs) are implicated in regulatory roles, controlling the expression of various genes in a cell under different conditions, including stress and stringent conditions [71]. Strand-specific RNA Seq could reveal such RNAs and provide insight into the mode of regulation of the genes of interest in the microorganism of interest. This process may offer dual advantage; firstly, the discovery of target small RNAs (sRNAs), and secondly, characterization of the effects of drug leads administered to the target pathogen [72]. Interestingly, the evidence is emerging to substantiate the involvement of small noncoding RNAs as regulatory molecules in the biosynthetic pathways of biologically active secondary metabolites in bacteria $[73,74]$. For instance, Saccharopolyspora erythraea is an actinomycete known to produce potent antimicrobial compounds, including the antibiotics oleandomycin erythromycin $[75,76]$. Liu and colleagues [73], described six sRNAs associated with secondary metabolism in S. erythraea, four of which were predicted to base-pair with secondary metabolite genes. This phenomenon is critical, especially for the optimization of conditions required for the biosynthesis of compounds of interest. In light of their potency in gene regulation, ncRNAs may stand out as attractive epigenetic modulators of biosynthetic pathways of the drug leads as well as silencers of pathogenic genes in infectious agents.

\subsection{CRISPR-Cas Systems and Their Relevance to Transcriptomics and Bioprospecting}

Clustered regularly interspaced short palindromic repeats (CRISPR) represent a group of bacterial and archaeal sequences that have emerged as a reliable tool of gene expression manipulation and genome editing mechanisms. CRISPR-Cas is a system that involves a noncoding RNA, RNA-caspase enzyme interaction, guiding genome or transcriptome editing, and gene expression alteration. CRISPR RNAs (crRNAs) bind to a Cas protein such as the widely studied Cas9, thereby forming a complex (CRISPR-Cas) which directs cleavage of the DNA or RNA target elements. It is now becoming more evident that cyanobacteria possess a range of CRISPR-Cas systems involved in a variety of gene expression alteration mechanisms [76]. Nevertheless, the numbers and types of CRISPR-Cas systems vary vastly among species and strains [76]. Identification of such systems in bacteria can aid in the prediction and manipulation of secondary metabolite gene expression patterns. To date, interest in the development of CRISPR-Cas-based genetic engineering has increased enormously. Tong et al. [77] devised a CRISPR-Cas9 method targeting two genes, actIORF1 (SCO5087) and actVB (SCO5092), from the actinorhodin biosynthetic gene cluster in Streptomyces coelicolor A3 (2), thereby facilitating actinomycetal gene manipulation. It has been demonstrated that the application of CRISPR-Cas9 has the potential for modification of the E. coli genome containing the mevalonate (MVA) 
biosynthetic pathway and increased terpenoid biosynthesis [78]. Recently, a bioinformatic pipeline (CRISPRdisco) has been developed with the ability to automatically decipher all the so far-known classes of CRISPR-Cas systems, offering an easy comparison with the published literature on CRISPR repeats and cas genes [79]. The application of CRISPR-Cas systems remains one of the promising advances in bioengineering, warranting effective in situ and ex-situ discovery of strains and metabolites of therapeutic and biotechnological relevance. In light of its more extensive application and specificity, a CRISPR-Cas system holds the potential for deciphering the molecular regulatory networks, microbial ecology as well as a genome editing tools for bioengineering towards production of desirable strains and genes of interest to drug discovery.

\section{Proteomics}

Proteomics involves studies on an entire set of proteins expressed by the genome (proteome) of a cell under certain conditions, giving rise to high-throughput data. Proteomics has dual functions; one is an approach to discover novel peptide drugs, and the second is for deciphering the mechanisms of action of drugs under study $[80,81]$. The application of proteomics has the potential for elucidation of downstream effects of a drug lead or an available drug and thereby determining whether it mediates side effects or induces drug resistance responses [82,83]. Proteins are the most prominent drug targets; thus, in the drug discovery, the ultimate value of the drug lead is its ability to bind to a target protein and alter the cell's biochemical processes. As opposed to transcriptomics that provides information on the number of target genes being transcribed to RNAs, proteomics reveals the genes that are eventually translated to peptides. Furthermore, proteomics, using mass spectrometry, coupled to other techniques, provides insight into posttranslational modifications of the proteins $[84,85]$.

\section{Glycomics}

Glycomics focuses on the characterization and quantification of carbohydrates and their conjugates, including proteoglycans, aminosugars, sulfoglycans, and glycolipids. Advances in biological databases have simplified research in bioprospecting of carbohydrates by providing references to several molecules from laboratory analysis. The major carbohydrate databases available include Glycosciences.de (GS) and Bacterial Carbohydrate Structure Database (BCSDB) [86]. Glycome profiling has the potential for both the characterization of biotechnologically important carbohydrate molecules as well as the determination of downstream effects of a drug administered to a pathogen [87]. In the characterization of metabolites, glycomics offers insight into various forms of carbohydrates produced by the target organism. On the other hand, glycome profiling provides a view of the forms of carbohydrates synthesized by a pathogen upon administration of a given dose of a drug lead or therapeutic drug. Glycomics is, therefore, essential for drug discovery and understanding the pharmacodynamics and pharmacokinetics of the drug. Besides, it also enables characterization of polysaccharides for various biotechnological industrial applications.

High-throughput screening of microbial samples for carbohydrates can be done using methods similar to those applied in peptide sequence analysis, giving rise to derivatives detectable and comparable to available molecules in glycome databases [88]. Microalgae are an excellent source of conjugated carbohydrates as agents of many therapeutic molecules, including immunomodulatory, anticancer, anti-inflammatory, antiviral, and antibacterial compounds [89,90]. For instance, Arthrospira, is a genus with multiple health benefits whose sulfated polysaccharides are known for their immunomodulatory and antiviral properties [87,88]. Spirulan from Arthrospira, carrageenan, and various forms of lipopolysaccharides from microalgae represent a few among many polysaccharides with desirable biological activities [87,91,92].

\section{Lipidomics}

Lipids are a diverse group of biomolecules comprising of heterogeneous chemistry with a limitless array of modifications. As opposed to the other biomolecules, a single lipid molecule 
consists of two more moieties with entirely different physical and chemical properties. Neutral lipids contain nonpolar hydrocarbon tails (fatty acyl chains) and glycerol or sterol, while in polar lipids, the glycerol or sterol moiety is further modified by the presence of sugar, phosphate, and/or sulfate groups in versatile chemical organizations. As a result, lipids have profoundly vast biological activities under different physiological settings. Lipidomics target water-insoluble forms of metabolites, constituting part of the membrane barriers. Lipidome profiling is crucial to understanding biosynthetic pathways in a microorganism as well as a way for better understanding the metabolic status of a cell [93]. Further, lipidomics can serve as an approach to chemotaxonomic characterization of microorganisms $[93,94]$. The polyketide synthase pathway is one of the noteworthy pathways that leads to the formation of several secondary metabolites and their derivatives in many organisms, including bacteria and microalgae $[75,95]$. Nevertheless, lipids are so diverse that most lipids produced as primary metabolites with or without structural modifications possess a wide range of biological activities related to therapeutic and nutraceutical value [94,96]. Microalgae are a potential source of essential fatty acids and numerous modified forms of lipids that portray various bioactivities [97,98]. Polyunsaturated fatty acids (PUFAs) are profoundly involved in the formation of biologically active forms of lipids. In microalgae, PUFAs have been found as significant components of polar lipids such as glycolipids, phospholipids, and betaines [99]. A summary representing examples of lipids and their derivatives is given in Table 2. Several microalgal-sulfated lipids have also been reported to hold varied biological activities. Sulfoquinovosyl diacylglycerols (sqdg) constitute a group of modified forms of glycolipid steroids and sphingolipid glycoconjugates produced by Arthrospira and Chlorella species [30,100,101]. Other most reported bioactive lipid-producing microalgae include diatoms, flagellates, and dinoflagellates [26,101,102].

Table 2. Examples of bioactive lipids from bacteria and microalgae.

\begin{tabular}{cccc}
\hline Lipid & Source Microorganisms & Bioactivity & Reference \\
\hline $\begin{array}{c}\text { Sulfoquinovosyldiacyl } \\
\text { glycerol (SQDG) }\end{array}$ & Spirulina spp., Chlorella spp., & Antiviral and & Pavlova lutheri \\
$\begin{array}{c}\text { Sulfoquinovosylmonoacyl } \\
\text { glycerol (SQMG) }\end{array}$ & Spirulina spp., Chlorella spp., & Antiviral and & Ans,94,103] \\
Gamma-linoleic acid & Pavlova lutheri & immunomodulatory & {$[94,104]$} \\
Alpha-linoleic acid & Arthrospira spp., Chlorella spp. & Neuroprotective & {$[106]$} \\
Kalkitoxin & Lyngbya majuscula & Neurotoxin & {$[107]$} \\
Antillatoxin & Lyngbya majuscula & Neurotoxin & {$[107]$} \\
\hline
\end{tabular}

Besides their biological activity, lipids could be profiled as markers for a metabolic pathway of interest [103]. Although lipid profiling is more common in human physiology than in the bioprospecting and drug discovery process, mapping the lipid profile in most algae is crucial not only for deciphering bioactive lipids but also for the biotechnological potential of the individual alga and the intrinsic biochemical pathways.

\section{Metabolomics}

The perturbation of a cell triggers genotypic responses that are manifested as variations in the metabolic phenotype. Under normal or abnormal circumstances, a cell undergoes a plethora of physiological states, each of which is associated with its specific forms and levels of metabolites qualitatively and quantitatively measurable at optimal levels. Metabolomics could represent a stand-alone branch of omics or as an approach integrated with proteomics, lipidomics, and glycomics [108,109]. Nevertheless, the focus of metabolomics is typically on small molecules $(<1500 \mathrm{Da})$ that are produced as a result of interactions between or among macromolecules. In the context of drug discovery, therefore, metabolomics is a tool for lead compounds, preclinical, clinical and safety screening, drug target identification, and pharmacological studies [110,111]. Interestingly, 
metabolomics receives support from chemistry and the integrated technologies, viz. high-resolution mass spectrometry, and nuclear magnetic resonance (NMR) in particular [111]. These methods render the study of metabolites feasible by coupling separation methods such as chromatography and capillary electrophoresis to spectroscopic analyses [112-114], which eventually provide a snapshot of the entire metabolome derived from precedented or unique molecules, giving rise to targeted or untargeted metabolic profiles, respectively.

\section{The Potential of Mass Spectrometry in Omics}

For decades, liquid chromatography-mass spectrometry (LC-MS) has been the most reliable method for the separation and detection of molecules of different nature. Liquid chromatography assures the separation of molecules in a complex mixture based on their chemical interaction with the column, which determines their retention time and elution from a chromatographic column. Following fragmentation and ionization, mass spectrometry (MS) assigns the fragments to measured spectra of appropriate masses. For instance, in proteomics, tandem mass spectrometry (MS/MS) involves downstream fragmentation, and further ionization of candidate proteins and the resulting peptide sequences are measured to obtain spectra comparable to theoretical spectra initially derived from in silico digestion of background database proteins [85,115]. Moreover, this method is emerging as a reliable technique to identify certain microorganisms by profiling the peptide sequences unique to a particular taxon $[115,116]$, thereby providing a high-throughput community characterization and identification of selected microbial species [117-119]. Interestingly, MS allows the identification of posttranslational modifications of proteins, their targets, and the attachment site [85]. With the application of high-resolution MS (HRMS), the downstream metabolic output can be monitored in a bid to establish information linking molecular, biochemical, and physiological processes in a target cell.

Matrix-assisted laser desorption ionization-time of flight mass spectrometry (MALDI-TOF/MS) has emerged as a powerful approach for screening numerous molecules in microbial samples [116]. The fascinating aspect of MALDI-MS is the suitability for analyzing macromolecules such as polysaccharides, lipids, or proteins or nucleic acids with desirable resolution without disruption of their integrity $[117,118]$. For instance, proteins digested and separated with gel electrophoresis or reverse-phase liquid chromatography (RP-LC) are ionized with limited fragmentation and analyzed with MADI-TOF MS [119]. The method can further the identification of unique pathways and novel compounds in cyanobacteria, leading to the identification of possible marker proteins in intact cells [120]. For the first time in cyanobacteria, a team of researchers [121] employed MALDI-TOF MS and successfully identified 31 out of 52 ribosomal protein subunits in Microcystis aeruginosa strains of cyanobacteria, which facilitated the classification of the strains to their five clades, two of which were recognized as non-toxic while the remaining three were toxic. These findings promise a rapid and robust guide towards strain choice and their biotechnological application. The robustness of MALDI-TOF/MS provides insight into the in situ monitoring of a metabolic repertoire. In 2018, a group of researchers [120] managed to visualize photosystem proteins, phycobilisome proteins, electron transport proteins, nitrogen metabolism, and nucleic acid binding-proteins, cytochromes plus other enzymes from intact cyanobacterial cells. This in situ visualization is essential for the instant correlation of cultivation conditions to metabolic dynamics of the microbe under investigation, a guide towards the selection of appropriate molecular and biochemical blueprints underpinning the functional traits of interest.

Mass spectrometry-based metabolomics has enabled the profiling of metabolites even in an intact homogenous or heterogeneous mixture of cells [122]. For example, jamaicamide B, curacin A, and curazole, along with 40 ionic fragments corresponding to secondary marine cyanobacterial metabolites were detected using natural product MALDI-TOF (npMALDI-TOF) imaging [123]. With the cultivation and metabolic challenges of most bacteria and microalgae, the metabolic dynamics at different growth stages could, therefore, be monitored by the application of MALDI-TOF/MS. Another study demonstrated through NMR fingerprinting that administration of $N$-acetyl-D-glucosamine to 
actinomycetes Micromonospora sp. RV43, Rhodococcus sp. RV157, and Actinokineospora sp. EG49 triggers the production of 3-formylindole and guaymasol, bacillibactin and surfactin, as well as actinosporins, respectively [124]. Employing high-density cultivation coupled to HPLC-MALDI-TOF/MS and NMR, Guljamow et al. [65] characterized the secondary metabolites nostopeptolide, nostamide A, and anabaenopectin, from the cyanobacterium Nostoc punctiforme. These findings strongly support the insight that the biosynthetic gene clusters (BGCs) involved in the secondary metabolism in Nostoc spp. and related filamentous cyanobacteria are activated by extracellular signaling, as demonstrated by ultrahigh density culture with shaking in continuous light and carbon dioxide [125]. The current advancement in data science, with the rapid expansion of up-to-date databases, promises better integration of MS data with genomics for accurate characterization of microorganisms and interest in the drug discovery endeavor.

\section{Biosynthetic Pathways of Drug Leads and Heterologous Expression}

Bacteria and microalgae synthesize compounds through a wide range of biochemical pathways comprising several enzyme-catalyzed chemical reactions. Non-ribosomal peptides (NRPs) and polyketides represent a well-established class of natural products holding a wide array of biological activities such as anti-inflammatory, anticancer, antiviral, and antimicrobial activities [38,126]. Identification of secondary metabolite biosynthetic gene clusters (BGCs) by genomics offers an advantage to screen the genes or strains and optimize conditions for the production of secondary metabolites of interest. Alternatively, ribosomally synthesized and post-translationally modified peptides (RiPPs) represent quite many biologically active molecules from the primary biosynthetic pathways [127]. Apart from peptides, various saccharides and lipids are also synthesized from primary metabolic pathways and possess a wide range of bioactivities from antiviral, immunomodulatory, anticancer, to cardio-modulatory effects [94,128,129].

Recent advances in bioinformatics have accelerated the screening of genes for secondary metabolite predictions. Among the well-established databases include the antibiotics and Secondary Metabolites Analysis SHell (anti-SMASH), the antiSMASH database, Prediction Informatics for Secondary Metabolomes (PRISM), Global Alignment for Natural-products Cheminformatics (GARLIC), Generalized Retrobiosynthetic Assembly Prediction Engine (GRAPE) platform, and IMG/ABC [13,130,131]. The databases offer a platform for various analyses including alignment of gene cluster level to their nearest relatives from a database containing all other known gene clusters, mining of microbial genes and prediction of secondary metabolites such as terpene, ribosomal peptide, and non-ribosomal peptide BGCs, comparative alignment of trans-AT polyketide synthase (PKS) assembly lines, and TTA codon annotation, among others [127,129]. Through the identification of pathways, these databases warrant leveraged screening and appropriate selection of strains with potential for specific drug leads of interest. Moreover, gene mining potentially opens up a way for selected heterologous expression of the secondary metabolite genes for uncultivable microbes $[13,126]$.

A good number of bacterial and microalgal genes have been harvested, cloned and expressed in Escherichia coli, one of the most readily cultivable bacteria, which has rendered itself a cell factory for many genes over decades [126]. Other surrogate factories commonly used include Streptomyces coelicolor, Streptomyces lividans, Bacillus subtilis, Pseudomonas putida, Saccharomyces cerevisiae, and Aspergillus nidulans [126]. Table 3 presents some of the selected bacterial and microalgal genes produced recombinantly. The increase in genome databases could, therefore, stimulate an attractive prospect for novel natural product gene discovery and development of drugs via strain cultivation or recombinant and heterologous expression approaches. 
Table 3. Examples of heterologously expressed genes for biosynthetic pathways of selected biologically active compounds from bacteria and microalgae.

\begin{tabular}{|c|c|c|c|c|c|c|}
\hline Metabolite & $\begin{array}{l}\text { Metabolite } \\
\text { Classes }\end{array}$ & Gene & $\begin{array}{c}\text { Source } \\
\text { Microorganism }\end{array}$ & Bioactivities & Factory & Reference \\
\hline Lyngbyatoxin & NRP & NRPS & $\begin{array}{l}\text { Lyngbya } \\
\text { majuscula }\end{array}$ & Anticancer & E. coli & [18] \\
\hline Epoxomicin & NRP/PK & $\begin{array}{l}\text { NRPS/PKS } \\
\text { complex }\end{array}$ & $\begin{array}{l}\text { S. hygroscopicus } \\
\text { ATCC } 53904\end{array}$ & $\begin{array}{l}\text { Anti-inflammatory, } \\
\text { Anticancer, } \\
\text { Antiplasmodium }\end{array}$ & S. albus J1046 & [132] \\
\hline Eponemycin & NRP & $\begin{array}{l}\text { NRPS/PKS } \\
\text { complex }\end{array}$ & $\begin{array}{l}\text { S. hygroscopicus } \\
\text { ATCC } 53709\end{array}$ & $\begin{array}{l}\text { Anti-inflammatory, } \\
\text { Anticancer, } \\
\text { Antiplasmodium }\end{array}$ & S. albus J1046 & [132] \\
\hline $\begin{array}{c}\text { Cyanovirin } \\
\mathrm{N}\end{array}$ & RP & RiPPs & $\begin{array}{c}\text { Nostoc } \\
\text { ellipsosporum }\end{array}$ & Antiviral & E. coli & [133] \\
\hline Oleandomycin & PKS & OlePKS & $\begin{array}{l}\text { Streptomyces } \\
\text { antibioticus }\end{array}$ & Antibacterial & $\begin{array}{c}\text { Saccharopolyspora } \\
\text { erythraea }\end{array}$ & [74] \\
\hline Cinnamycin & $\mathrm{RP}$ & RiPPs & & Antibiotic & S. albus & [130] \\
\hline
\end{tabular}

Biosynthetic pathway analysis is accomplished by transcriptomic profiling of the genome or the metagenome in question (i.e., metatranscriptomics). Application of transcriptomics unravels the pattern of expression of genes encoding enzymes involved in the biosynthetic pathways of a given compound under different conditions. The study of differential gene expression is a useful approach that can decipher the molecular adaptation of the microbes and establish optimal conditions for the biosynthesis of a drug lead of interest [12].

\section{One Strain Many Compounds (OSMAC) Approach in Omics}

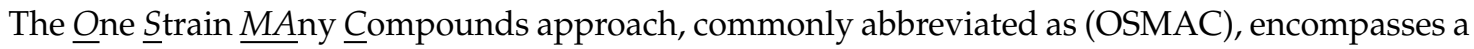
comprehensive and powerful tool for discovering a plethora of compounds from a single microorganism based on variation of the accessible cultivation conditions in a bid to mimic the natural environment of the microorganism under study [134]. The tradition has been to alter conditions in axenic cultures by alteration of physicochemical conditions and culture media and focus on a compound of interest. A broad class of microbial secondary metabolite pathways typically remain silent under in vitro cultivation conditions. The OSMAC approach has demonstrated remarkable results that yield an enhanced and versatile environment under laboratory cultivation conditions [135]. As of 2002, OSMAC opened up an avenue for the improved combinatorial and high-throughput elucidation of intricate molecular and chemical processes leading to the production of hundreds of compounds in one experiment [136]. An increase in understanding of the multiplicity of factors influencing the biosynthesis of compounds has spiked interest in the in situ exploration of microbial response to the environment for the sake of establishing stable conditions for target compounds. OSMAC methods have been used as an approach to enhance chemical diversity in microorganisms subjected to various cultivation conditions [137-139] (Figure 4).

Microbial metabolic pathways, irrespective of the ecological niche, principally offer possibilities of intervention in the synthesis of secondary metabolites; production can be influenced at the molecular level by modulating the accessible culture conditions in the laboratory. Variation of culture conditions includes adjusting physicochemical parameters such as temperature, $\mathrm{pH}$, nitrogen source, carbon source, light, and employing co-culture [138-140]. For example, it was observed in one study that a co-culture of Streptomyces rapamycinicus promotes biosynthesis of meroterpenoids and prenylated polyketides via the polyketide synthase pathway in a human pathogenic fungus Aspergillus fumigatus [137]. A similar study by Abdelwab and colleagues [138] using the OSMAC approach revealed a diverse range of cryptic metabolites on a co-culture of the bacteria Bacillus subtilis $168 \operatorname{trpC} 2$ and the endophytic fungus Aspergillus versicolor KU258497. With the application of OSMAC, bacteria can be challenged by bacteria or other microorganisms to induce silent gene pathways. This is of critical relevance, especially when the bacteria can be incited by human pathogens mimicking the infection defense mechanisms. Recent work in the actinobacteria Lentzea violacea strain AS08 revealed three biologically 
active compounds via the application of the OSMAC approach [134]. Eckelmann et al. [141] identified and characterized seven prodiginines and 26 serratamolides from an endophytic bacterial strain Serratia marcescens MSRBB2 isolated from the stem of the medicinal plant Maytenus serrata by employing dual co-culture with endophytic fungi, through the combination of HPLC-high-resolution mass spectrometry $\left(\mathrm{HRMS}^{\mathrm{n}}\right)$, scanning electron microscopy (SEM), and MALDI-imaging high-resolution mass spectrometry (MALDI-imaging HRMS). By combining such advanced analytical methods, OSMAC warrants a broader chance of unraveling multiple compounds from one strain, with compound structural characterization. Furthermore, OSMAC offers a powerful approach towards gaining insights into biosynthetic pathways and their distribution within a single strain or a community of endophytic microbes in collaboration with their host [141]. An intriguing co-evolved biosynthetic pathway of maytansine, a potent anticancer and cytotoxic compound, was observed in a landmark study by Kusari and colleagues [142]. This study revealed that selective crosstalk within a community of endophytic bacteria hiding in the roots of Putterlickia plants leads to the biosynthesis of maytansine. This finding rectified the previous misapprehension that maytansine is produced by Putterlickia plants rather than bacteria residing in the plant.

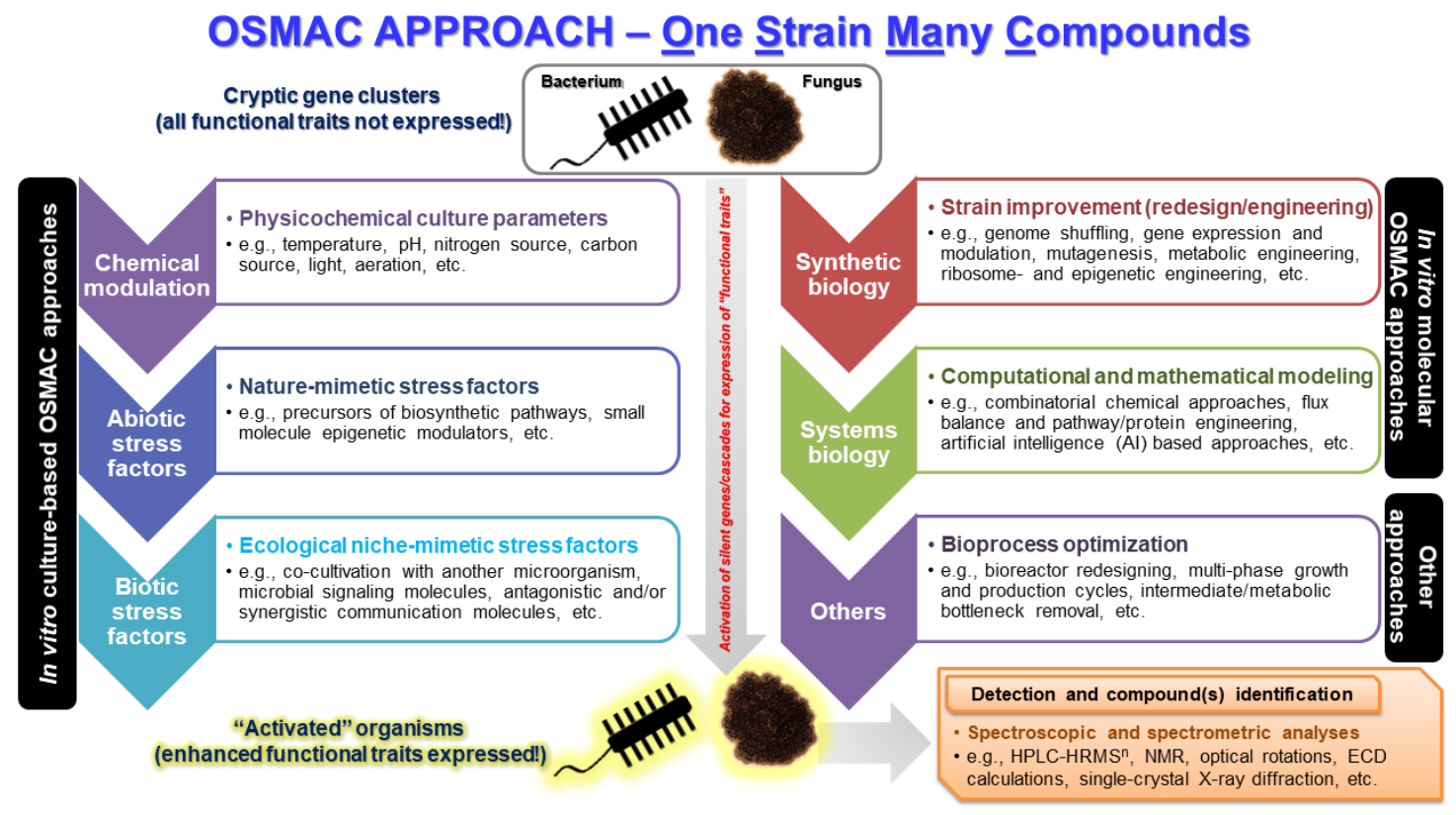

Figure 4. A typical workflow of the OSMAC approach for the discovery of versatile drug leads.

Host-microbe interaction is critical to the dynamics in the gene expression patterns and determines coevolution among the interacting organisms [143-145]. Similarly, interactions among members of a microbial community have potential synergistic molecular effects accounting for the production of an assortment of metabolites [125,142]. Hagihara et al. [68] described the interaction of Streptomyces davawensis and Tsukamurella pulmonis TP-B0596 under combined culture conditions, triggering biosynthesis of three desferrioxamine derivatives via a nitrous acid pathway. Interactions among bacteria and microalgae have also been found to exhibit remarkable dynamics in primary as well as secondary metabolic pathways [145]. These interactions may also have antagonistic effects [146-149], suggesting their importance as focal parameters in bioprospecting. Recently, a study revealed that the introduction of bacteria in the microalga Emiliania huxleyi culture triggers microalgal mortality via oxidative stress and apoptosis induced by bacterial production of indole-3-acetic acid [146]. These findings underscore the need for the OSMAC approach to omics-based bioprospecting and characterization of potential metabolic pathways involved in the production of more relevant drug leads. 


\section{Bioinformatics and Chemoinformatics Crosstalk in Drug Discovery from Bacteria and Microalgae}

Over the years, multiple screening experiments have been carried out with promising early findings, but with disappointing progress towards translational use [106,148]. Conventionally, elucidation of the mechanism of action (MOA) of compounds has been performed based on indirect and direct approaches [107]. While the indirect approach focuses on similarity in phenotypic effects of structurally unrelated compounds [149], a direct approach employs omics-chromatographic-MS combination in screening of direct interaction between the drug candidate and its molecular target [150].

The vast advent in computational and data sciences has emerged with renewed interest in more effective and accurate drug discovery and development in what is known as computer-aided drug design (CADD). The development of such virtual screening tools represents a remarkable milestone in the drug discovery arena, saving millions of funds that could be lost for years in wet laboratory science with unsuccessful in vitro and in vivo screening. For example, screening by computer-aided drug design has led to the discovery and identification of several bacterial and microalgal compounds (Figure 5), demonstrating their relevance in vitro and promising further testing.<smiles>CCCC/C=C/CCCC(=O)O</smiles>

(a)<smiles>CCCCCCCC(=O)O</smiles>

(b)<smiles>C/C=C(/CCC(C)C1CCC2C3CC=C4CCCCC4(C)C3CCC12C)C(C)C</smiles>

(c)

(d)

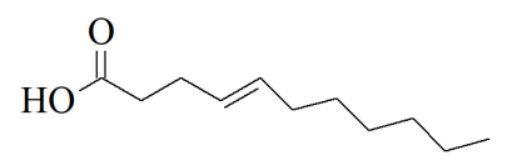

(e)

Figure 5. Chemical structures of some selected bacterial and microalgal compounds screened by computer-aided drug design, demonstrating their relevance in vitro and promising further testing. (a) (E)-dec-5-enoic acid; (b) heptanoic acid; (c) (E)-17-(5-isopropylhept-5-en-2-yl)-10,13-dimethyl 2,3,4,7,8,9,10,11,12,13,14,15,16,17-tetradecahydro-1H-cyclopenta[a]phenanthrene; (d) 17-(5-ethyl-6methylheptan-2-yl)-10,13-dimethyl 2,3,4,7,8,9,10,11,12,13,14,15,16,17-tetradecahydro-1H-cyclopenta[a]phenanthrene; (e) (E)-undec-4-enoic acid.

Today, with the availability of drug and secondary metabolite databases, preliminary assessment of the compounds identified via omics can be done by utilizing similarity search tools and associated chemical and biological activity data [151,152] (Table 4). Novel candidate molecules can be characterized using virtual screening bioinformatics software to decipher their molecular targets, and thenceforth establish a scaffold for structure-functional relationship analysis before laboratory-based bioassays $[153,154]$. The chemical diversity of metabolites produced by bacteria and microalgae is extensive such that carrying out in vitro or in vivo bioactivity screening for each molecule is not only laborious but also expensive. The microbe's adaptation to change a single group, several groups, or stereochemistry confers profound alteration in the biological activity and the pharmacological properties of the metabolites in question. A good number of compounds from cyanobacteria and 
microalgae are known to possess toxic effects in the animal and human body $[155,156]$, making such compounds undesirable drug leads. However, with the use of computer-aided screening, these molecules can be subjected to algorithms that could propose improved desirability regarding their bioactivity as well as pharmacology. Screening of crude extracts from various eukaryotic microalgae exhibits their remarkable potential as sources of antioxidant, anti-inflammatory, and anticancer drug leads [157]. Multiple omics-based approaches can be combined to yield quick and precise insights into credible bioactive candidates ("hits").

Table 4. Databases and software tools for virtual screening of drug leads.

\begin{tabular}{|c|c|c|c|}
\hline Tool & Database/Software & Application & URL \\
\hline DrugBank & Drug Database & $\begin{array}{l}\text { Pharmacological assessment of } \\
\text { compounds through search }\end{array}$ & $\begin{array}{c}\text { https: } \\
\text { //www.drugbank.ca }\end{array}$ \\
\hline BinBase & Metabolomic database & Similarity search for metabolites & $\begin{array}{l}\text { http://fiehnlab.ucdavis. } \\
\text { edu/projects/binbase_ } \\
\text { setupx\#binbase }\end{array}$ \\
\hline MetaboLights database & Metabolomic database & Search for metabolites & $\begin{array}{l}\text { https://www.ebi.ac.uk/ } \\
\text { metabolights/index }\end{array}$ \\
\hline HMDB & Metabolomic database & $\begin{array}{l}\text { Clinical chemistry, biomarker } \\
\text { discovery and general education }\end{array}$ & http://www.hmdb.ca/ \\
\hline Click2Drug & Browser/Database & $\begin{array}{l}\text { Search for integrated tools for } \\
\text { CADD }\end{array}$ & $\begin{array}{c}\text { https: } \\
\text { //www.click2drug.org/ }\end{array}$ \\
\hline PubChem & Database & Chemical molecule search & $\begin{array}{l}\text { https://pubchem.ncbi. } \\
\text { nlm.nih.gov/ }\end{array}$ \\
\hline SciFinder & Database & Chemical molecule search & $\begin{array}{l}\text { https://sso.cas.org/pf/ } \\
\text { metadata.ping }\end{array}$ \\
\hline LiSiCA & Software & $\begin{array}{c}\text { Searches for 2D and 3D } \\
\text { similarities between a reference } \\
\text { compound and a database of } \\
\text { target compounds }\end{array}$ & http://insilab.org/lisica/ \\
\hline MedChem Studio & Software & $\begin{array}{l}\text { Data visualization, compound } \\
\text { clustering, high throughput } \\
\text { screening analysis, lead } \\
\text { identification and prioritization, } \\
\text { de novo design, scaffold hopping, } \\
\text { lead optimization }\end{array}$ & $\begin{array}{c}\text { https: } \\
\text { //www.simulations-plus. } \\
\text { com/software/ } \\
\text { admetpredictor/ } \\
\text { medchem-studio/ }\end{array}$ \\
\hline PyRx & Software & $\begin{array}{c}\text { Virtual Screening for } \\
\text { Computational Drug Discovery, } \\
\text { target screening }\end{array}$ & $\begin{array}{c}\text { https: } \\
\text { //pyrx.sourceforge.io/ }\end{array}$ \\
\hline CRISPRdisco & Software & $\begin{array}{l}\text { Identification of CRISPR } \\
\text { repeat-spacer arrays and cas genes } \\
\text { in genome data sets }\end{array}$ & $\begin{array}{l}\text { https://github.com/ } \\
\text { crisprlab/CRISPRdisco }\end{array}$ \\
\hline
\end{tabular}

With the use of bioinformatic analysis tools, gene structure and functional annotation provide a clue to the potential of the drug-like gene, which could be coupled to pathway analysis and, finally, virtually confirmed by structure-based (SB) or ligand-based (LB) approach using chemoinformatic tools [158]. Recently, a novel compound named 9-ethyliminomethyl-12-(morpholin-4-ylmethoxy)-5,8,13,16-tetraaza-hexacene-2,3 dicarboxylic acid (EMTAHDCA) was characterized from Nostoc sp. and virtually screened by molecular docking using YASARA software and found to possess potency against Gram-negative bacteria, with efficacy comparable to commercially available drugs [154]. The quantitative structure-activity relationship (QSAR) method was applied to screen the molecular activity of brominated metabolites from the algae Dictyopteris hoytii. It portrayed the ability to inhibit the enzyme alpha-glucosidase [159]. This inhibition accounts for the potential of the compounds as antidiabetic and antiviral agents [160,161]. In QSAR studies by Davis and Vasanthi [162], selected algal metabolites from the Seaweed Metabolite Database (SWMD) demonstrated fascinating activity via inhibition of protein kinase B (PKB, aka Akt), accounting 
for their role as anticancer compounds. In this study, some of the compounds demonstrating plausible interaction with Akt were steroids and terpenoids having different properties. Bacteria and microalgae synthesize a large number of such metabolites, which through molecular docking, could offer exciting outcomes.

The application of in silico assays has increased accuracy for better prediction of the bioactivity and molecular target of the candidate molecules. Montone and colleagues [163] employed a high throughput screening of 500 peptide sequences by the PeptideRanker algorithm from the microalga Tetradesmus obliquus (also Scenedesmus) and found 25 antioxidant and angiotensin-converting enzyme (ACE)-inhibitory activities. Four of the 25 peptides were synthesized and confirmed for the same activities in vitro. With such findings, virtual screening could be applied to quickly tentatively identify bacterial or microalgal compounds before deployment of wet laboratory facilities. The increase in number and diversity of browsers, databases, and software promises a wide array of drug discoveries and more focused wet laboratory pharmacological studies, which can shorten the span for discovery and validation of a single drug.

\section{Future Prospects}

Advances in single-cell and single-molecule technologies have spiked profound leaps and bounds in the bioprospecting arena. The paradigm shift from single to multidisciplinary approaches intersecting biosciences, chemistry, and physics has the potential to revolutionize drug discovery and development, and accelerate the accuracy of drug discovery endeavor. As of today, computational science, through what is known as machine learning and artificial intelligence, can facilitate de novo drug design and propel the process of analysis faster than the human brain could perform [158]. In the near future, most challenges related to drug toxicity may be resolved through antibody and nanotechnology, which have emerged as methods to curtail chemotherapeutic toxicity by improving targeted drug delivery. Since most cyanobacterial compounds are toxic, their toxicity is of value against cancer cells. Moreover, computational science and machine learning have a greater potential to streamline drug discovery from bacteria and microalgae owing to their diverse ecological and metabolic continua. With CADD ventures, compounds that were discarded based on their undesirable absorption, distribution, metabolism, and excretion (ADME) characteristics can be retrieved and subjected to structural modifications and in silico simulations for future retesting and improvement.

\section{Conclusions}

Bacterial and microalgal communities represent vast sources of pharmacologically important metabolites. These communities are in a consortium of vast biodiversity encompassing plants, animals, zooplanktons, and fungi, with which they interact regularly. Their interactions and complex ecosystems revealed over the last three decades represent an almost untapped "druggable" compound diversity. Omics is one way to decipher the intricate network of metabolic interactions among biologically diverse organisms. Nevertheless, the increasing pace towards the discovery of novel strains and drug leads requires a corresponding increase in the development of bioinformatics and chemoinformatic tools and databases to materialize the goals of the endeavor. Notwithstanding the increase in secondary metabolite studies on bacteria and microalgae, a myriad of compounds at the preclinical or clinical trial stage, and even those that are commercially available, are yet to be accessible in the databases. Besides, their pharmacological properties, as well as their amenability to synthesis or modification, are less unraveled. Furthermore, the advances in modern generation analytical technologies and computational approaches need corresponding increases in skilled teams to develop more user-friendly tools and utilize the data for realistic drug discovery. This highlights the need for an interdisciplinary approach and training of young generations to suffice the available technologies and bring about more meaningful drug discovery from microorganisms. 
Author Contributions: R.M., S.K., and R.H.-K. conceptualized the review; R.M. wrote the first manuscript draft with inputs from D.D., A.M., S.S.N., S.L.L., S.K., and R.H.-K.; S.K. revised, reformatted, and finalized the manuscript; R.M. and S.K. prepared the tables and figures. All authors have read and agreed to the published version of the manuscript.

Funding: This work was funded in part by the Swedish International Development Agency (SIDA) Under Interdisciplinary Molecular Biosciences, Project no. IMB-2015/2020. Research in the laboratory of S.K. is supported in part by the German Federal Ministry of Education and Research (BMBF; grant no. 031B0512E); German Academic Exchange Service (DAAD); the Ministry of Innovation, Science, Research, and Technology of the State of North Rhine-Westphalia; German Research Foundation (DFG); and TU Dortmund, Germany.

Acknowledgments: R.M. thankfully acknowledges Professor Erik Bongcam-Rudloff, Department of Animal Breeding and Genetics, Bioinformatics, Swedish University of Agricultural Science (SLU), Sweden for valuable discussions and advice on different aspects of drug discovery.

Conflicts of Interest: The authors declare no conflict of interest.

\section{References}

1. Buenz, E.J.; Verpoorte, R.; Bauer, B.A. The ethnopharmacologic contribution to bioprospecting natural products. Annu. Rev. Pharmacol. Toxicol. 2018, 5, 509-530. [CrossRef] [PubMed]

2. Soejarto, D.D.; Fong, H.H.S.; Tan, G.T.; Zhang, H.J.; Ma, C.Y.; Franzblau, S.G.; Gyllenhaal, C.; Riley, M.C.; Kadushin, M.R.; Pezzuto, J.M.; et al. Ethnobotany/ethnopharmacology and mass bioprospecting: Issues on intellectual property and benefit-sharing. J. Ethnopharmacol. 2005, 100, 15-22. [CrossRef] [PubMed]

3. Mate, N.; Nader, W.; Tamayo, G. Encyclopeida of Biodiversity; Levin, S.E., Ed.; Academic Press: Cambridge, MA, USA, 2013; Volume 1, pp. 571-579.

4. Maldonado, L.A.; Stach, J.; Pathom-aree, W.; Ward, A.C.; Bull, A.T.; Goodfellow, M. Diversity of cultivable actinobacteria in geographically widespread marine sediments. Antonie Van Leeuwenhoek 2005, 87, 11-18. [CrossRef] [PubMed]

5. Chang, Y.; Wu, Z.; Bian, L.; Feng, D.; Leung, D.Y.C. Cultivation of Spirulina platensis for biomass production and nutrient removal from synthetic human urine. Appl. Energy 2013, 102, 427-431. [CrossRef]

6. Aoi, Y.; Kinoshita, T.; Hata, T.; Ohta, H.; Obokata, H.; Tsuneda, S. Hollow-fiber membrane chamber as a device for in situ environmental cultivation. Appl. Environ. Microbiol. 2009, 75, 3826-3833. [CrossRef]

7. Stengel, D.B.; Connan, S.; Popper, Z.A. Algal chemodiversity and bioactivity: Sources of natural variability and implications for commercial application. Biotechnol. Adv. 2011, 29, 483-501. [CrossRef]

8. Aziz, F.H. Fikrat; M.H.; Rasul, B.H. An ecological observation on inland water ecosystem in Erbil-Iraq Kurdistan with particular reference to blue green algae Glaucospira. J. Baghdad Sci. 2014, 11, 1385-1387.

9. Szubert, K.; Wiglusz, M.; Mazur-Marzec, H. Bioactive metabolites produced by Spirulina subsalsa from the Baltic Sea. Oceanologia 2018, 60, 245-255. [CrossRef]

10. Huang, X.; Pinto, D.; Fritz, G.; Mascher, T. Environmental sensing in actinobacteria : A comprehensive survey on the signaling capacity of this phylum. J. Bacteriol. 2015, 197, 2517-2535. [CrossRef]

11. Vester, J.K.; Glaring, M.A.; Stougaard, P. Improved cultivation and metagenomics as new tools for bioprospecting in cold environments. Extremophiles 2015, 19, 17-29. [CrossRef]

12. Hemaiswarya, S.; Raja, R.; Ravikumar, R.; Kumar, A.; Carvalho, I. Omics: Applications in Biomedical, Agricultural, and Environmental Sciences; Barh, D., Zambare, V., Azevedo, V., Eds.; CRC Press: Boca Raton, FL, USA; Taylor and Francis: London, UK, 2013; Chapter 18, p. 439. [CrossRef]

13. Marco, D.E.; Abram, F. Using Genomics, Metagenomics and Other "Omics" to Assess Valuable Microbial Ecosystem Services and Novel Biotechnological Applications. Front. Microbiol. 2019, 10, 151. [CrossRef] [PubMed]

14. Munang'andu, H.M.; Mugimba, K.K.; Byarugaba, D.K.; Mutoloki, S.; Evensen, Ø. Current advances on virus discovery and diagnostic role of viral metagenomics in aquatic organisms. Front. Microbiol. 2017, 8, e406. [CrossRef] [PubMed]

15. Carruthers, M.; Yurchenko, A.A.; Augley, J.J.; Adams, C.E.; Herzyk, P.; Elmer, K.R. De novo transcriptome assembly, annotation and comparison of four ecological and evolutionary model salmonid fish species. BMC Genom. 2018, 19, 1-39. [CrossRef]

16. Mills, J.D.; Kawahara, Y.; Janitz, M. Strand-specific RNA-Seq provides greater resolution of transcriptome profiling. Curr. Genom. 2013, 173-181. [CrossRef] [PubMed] 
17. Kodzius, R.; Gojobori, T. Marine genomics marine metagenomics as a source for bioprospecting. Mar. Genom. 2015, 24, 21-30. [CrossRef] [PubMed]

18. Jiménez, D.J.; Andreote, F.D.; Chaves, D.; Montan, S.; Jime, D.J.; Zambrano, M.; Baena, S.; Osorio-forero, C.; Junca, H. Structural and functional insights from the metagenome of an acidic hot spring microbial planktonic community in the Colombian Andes. PLoS ONE 2012, 7, e52069. [CrossRef]

19. Chaudhary, A.K.; Dhakal, D.; Sohng, J.K. An insight into the "-omics" based engineering of streptomycetes for secondary metabolite overproduction. BioMed Res. Int. 2013, 968518. [CrossRef]

20. Rai, V.; Karthikaichamy, V.; Das, D.; Noronha, S.; Wangikar, P.P.; Srivastava, S. Multi-omics Frontiers in Algal Research: Techniques and Progress to Explore Biofuels in the Postgenomics World. OMICS 2016, 20, 387-399. [CrossRef]

21. Ramos, P.I.; Porto, D.F.; Lanzatotti, E.; Sosa, E.J.; Burguener, G.; Pardo, A.M.; Klein, C.C.; Sagot, M.-F.; De Vasconcelos, A.T.R.; Gales, A.C.; et al. An integrative, multi-omics approach towards the prioritization of Klebsiella pneumoniae drug targets. Sci. Rep. 2018, 8, 10755. [CrossRef]

22. Kuppusamy, P.; Soundharrajan, I.; Srigopalram, S.; Yusoff, M.M. Potential pharmaceutical and biomedical applications of Diatoms microalgae-An overview. Ind. J. Geo Mar. Sci. 2017, 46, 663-667.

23. Wang, M.; Zhang, J.; He, S.; Yan, X. A review study on macrolides isolated from cyanobacteria. Mar. Drugs 2017, 15, 126. [CrossRef] [PubMed]

24. Kobayashi, J. Amphidinolides and its related macrolides from marine dinoflagellates. J. Antibiot. (Tokyo) 2008, 61, 271-284. [CrossRef] [PubMed]

25. Challis, G.L.; Hopwood, D.A. Synergy and contingency as driving forces for the evolution of multiple secondary metabolite production by Streptomyces species. Proc. Natl. Acad. Sci. USA 2003, 100, 14555-14561. [CrossRef] [PubMed]

26. Hielscher-Michael, S.; Griehl, C.; Buchholz, M.; Demuth, H.U.; Arnold, N.; Wessjohann, L.A. Natural products from microalgae with potential against Alzheimer's disease: Sulfolipids are potent glutaminyl cyclase inhibitors. Mar. Drugs 2016, 14, 203. [CrossRef]

27. Lin, P.-Y.; Tsai, C.-T.; Chuang, W.-L.; Chao, Y.-H.; Pan, I.-H.; Chen, Y.-K.; Lin, C.-C.; Wang, B.-Y. Chlorella sorokiniana induces mitochondrial-mediated apoptosis in human non-small cell lung cancer cells and inhibits xenograft tumor growth in vivo. BMC Complement. Altern. Med. 2017, 17, 1-88. [CrossRef]

28. Shannon, E.; Abu-Ghannam, N. Antibacterial derivatives of marine algae: An overview of pharmacological mechanisms and applications. Mar. Drugs 2016, 14, 81. [CrossRef]

29. Yamada, Y.; Kuzuyama, T.; Komatsu, M.; Shin-ya, K.; Omura, S.; Cane, D.E.; Ikeda, H. Terpene synthases are widely distributed in bacteria. Proc. Natl. Acad. Sci. USA 2015, 112, 857-862. [CrossRef]

30. López, Y.; Soto, S.M. The preventing usefulness biofilm microalgae infections compounds for preventing biofilm infections. Antibiotics 2020, 9, 9. [CrossRef]

31. Sambanthamoorthy, K.; Gokhale, A.A.; Lao, W.; Parashar, V.; Neiditch, M.B.; Semmelhack, M.F.; Lee, I.; Waters, C.M. Identification of a novel benzimidazole that inhibits bacterial biofilm formation in a broad-spectrum manner. Antimicrob. Agents Chemother. 2011, 55, 4369-4378. [CrossRef]

32. Sorokin, D.Y.; Berben, T. Microbial diversity and biogeochemical cycling in soda lakes. Extremophiles 2014, 791-809. [CrossRef]

33. Nolla-ardèvol, V.; Strous, M.; Tegetmeyer, H.E.; Oren, A. Anaerobic digestion of the microalga Spirulina at extreme alkaline conditions: Biogas production, metagenome, and metatranscriptome. Front. Microbiol. 2015, 6, 597. [CrossRef] [PubMed]

34. Alkhalili, R.N.; Hatti-kaul, R.; Canbäck, B. Genome Sequence of Geobacillus sp. Strain ZGt-1, an Antibacterial Peptide-Producing Bacterium from Hot Springs in Jordan. Genome Announc. 2015, 3, e00799-15. [CrossRef] [PubMed]

35. Alkhalili, R.N.; Bernfur, K.; Dishisha, T.; Mamo, G.; Schelin, J.; Canbäck, B.; Emanuelsson, C.; Hatti-Kaul, R. Antimicrobial protein candidates from the thermophilic Geobacillus sp. Strain ZGt-1: Production, proteomics, and bioinformatics analysis. Int. J. Mol. Sci. 2016, 17, 1363. [CrossRef] [PubMed]

36. Kwei, C.K.; Lewis, D.; King, K.; Donohue, W.; Neilan, B.A. Molecular classification of commercial Spirulina strains and identification of their sulfolipid biosynthesis genes. J. Microbiol. Biotechnol. 2011, 21, 359-365. [PubMed]

37. Groendahl, S.; Kahlert, M.; Fink, P. The best of both worlds: A combined approach for analyzing microalgal diversity via metabarcoding and morphology-based methods. PLoS ONE 2017, 12, e0172808. [CrossRef] 
38. Franzén, O.; Hu, J.; Bao, X.; Itzkowitz, S.H.; Peter, I.; Bashir, A. Improved OTU-picking using long-read 16S rRNA gene amplicon sequencing and generic hierarchical clustering. Microbiome 2015, 43. [CrossRef]

39. Preetha, K.; John, L.; Subin, C.S.; Vijayan, K.K. Phenotypic and genetic characterization of Dunaliella (Chlorophyta) from Indian salinas and their diversity. Aquat. Biosyst. 2012, 8, 27. [CrossRef] [PubMed]

40. Jovel, J.; Patterson, J.; Wang, W.; Hotte, N.; O’Keefe, S.; Mitchel, T.; Perry, T.; Kao, D.; Mason, A.L.; Madsen, K.L.; et al. Characterization of the gut microbiome using $16 \mathrm{~S}$ or shotgun metagenomics. Front. Microbiol. 2016, 7 , 459. [CrossRef] [PubMed]

41. Godoy-Vitorino, F.; Romaguera, J.; Zhao, C.; Vargas-Robles, D.; Ortiz-Morales, G.; Vázquez-Sánchez, F.; Sanchez-Vázquez, M.; De La Garza-Casillas, M.; Martinez-Ferrer, M.; White, J.R.; et al. Cervicovaginal fungi and bacteria associated with cervical intraepithelial neoplasia and high-risk human papillomavirus infections in a hispanic population. Front. Microbiol. 2018, 9, 2533. [CrossRef]

42. Perkerson, R.B., III; Perkerson, E.A.; Casamatta, D.A. Phylogenetic examination of the cyanobacterial genera Geitlerinema and Limnothrix (Pseudanabaenaceae) using 16S rDNA gene sequence data. Arch. Hydrobiol. Suppl. Algol. Stud. 2010, 134,1-16. [CrossRef]

43. Scheldeman, P.; Baurain, D.; Bouhy, R.; Scott, M.; Mühling, M.; Whitton, B.A.; Belay, A.; Wilmotte, A. Arthrospira ('Spirulina') strains from four continents are resolved into only two clusters, based on amplified ribosomal DNA restriction analysis of the internally transcribed spacer. FEMS Microbiol. Lett. 1999, 172, 213-222. [CrossRef] [PubMed]

44. Burgess, S.A.; Flint, S.H.; Lindsay, D.; Cox, M.P.; Biggs, P.J. Insights into the Geobacillus stearothermophilus species based on phylogenomic principles. BMC Microbiol. 2017, 17, 140. [CrossRef] [PubMed]

45. Chèneby, D.; Philippot, L.; Hartmann, A.; Hénault, C.; Germon, J.C. 16S rDNA analysis for characterization of denitrifying bacteria isolated from three agricultural soils. FEMS Microbiol. Ecol. 2000, 34, 121-128. [CrossRef]

46. Alanagreh, L.; Pegg, C.; Harikumar, A.; Buchheim, M. Assessing intragenomic variation of the internal transcribed spacer two: Adapting the Illumina metagenomics protocol. PLoS ONE 2017, 12, e0181491. [CrossRef] [PubMed]

47. Lafontaine, D.L.J.; Tollervey, D. The function and synthesis of ribosomes. Nat. Rev. Mol. Cell Biol. 2001, 2, 514-520. [CrossRef] [PubMed]

48. Tesson, S.V.M.; Šantl-temkiv, T.; Dillon, J.G. Ice nucleation activity and aeolian dispersal success in airborne and aquatic microalgae. Front Microbiol. 2018, 9, e2681. [CrossRef]

49. Hadi, S.I.I.A.; Santana, H.; Brunale, P.P.M.; Gomes, T.G. DNA barcoding green microalgae isolated from neotropical inland waters. PLOS ONE 2016, 11, e0149284. [CrossRef]

50. Patel, A.; Chaudhary, S.; Syed, B.A.; Gami, B.; Patel, P. Rbcl marker based approach for molecular identification of Arthrospira and Dunaliella isolates from non-axenic cultures. J. Genet. Genet. Eng. 2018, 2, 24-34.

51. Duong, V.T.; Ahmed, F.; Thomas-hall, S.R.; Quigley, S.; Nowak, E.; Schenk, P.M. High protein- and high lipid-producing microalgae from northern Australia as potential feedstock for animal feed and biodiesel. Front. Bioeng. Biotechnol. 2015, 3, 53. [CrossRef]

52. Gantner, S.; Stenlid, J. Utilizing ITS1 and ITS2 to study environmental fungal diversity using pyrosequencing. FEMS Microbiol. Ecol. 2012, 84, 165-175. [CrossRef]

53. Walter, J.M.; Coutinho, F.H.; Dutilh, B.E.; Thompson, C.C.; Thompson, F.L. Proposal of a new genome-based taxonomy for Cyanobacteria. Front. Microbiol. 2016, 8, e02132. [CrossRef]

54. Nolla-ardèvol, V.; Peces, M.; Strous, M.; Tegetmeyer, H.E. Metagenome from a Spirulina digesting biogas reactor: Analysis via binning of contigs and classification of short reads. BMC Microbiol. 2015, 15, e277. [CrossRef] [PubMed]

55. Krohn-molt, I.; Wemheuer, B.; Alawi, M.; Poehlein, A.; Schmeisser, C.; Grundhoff, A.; Daniel, R.; Hanelt, D.; Streit, W.R. Metagenome Survey of a multispecies and alga-associated biofilm revealed key elements of bacterial-algal interactions in photobioreactors. Appl. Environ. Microbiol. 2013, 79, 6196-6206. [CrossRef] [PubMed]

56. Pryszcz, L.P.; Santos, F. Interactions between closely related bacterial strains are revealed by deep transcriptome sequencing. Appl. Environ. Microbiol. 2015, 81, 8445-8456. [CrossRef]

57. Sharma, G.; Dua, P.; Agarwal, S. A comprehensive review of dysregulated miRNAs involved in cervical cancer. Curr. Genom. 2014, 15, 310-323. [CrossRef] 
58. Peter, A.P.; Lakshmanan, K.; Mohandass, S. Cyanobacterial KnowledgeBase ( CKB ), a compendium of cyanobacterial genomes and proteomes. PLOS ONE 2015, 10, e0136262. [CrossRef]

59. Xu, T.; Qin, S.; Hu, Y.; Song, Z.; Ying, J.; Li, P.; Dong, W.; Zhao, F.; Yang, H.; Bao, Q. Whole genomic DNA sequencing and comparative genomic analysis of Arthrospira platensis: High genome plasticity and genetic diversity. DNA Res. 2016, 23, 325-338. [CrossRef]

60. Parks, D.; Chuvochina, M.; Waite, D.; Rinke, C.; Skarshewisk, A.; Chaumeil, P.-A.; Hungeholtz, P. A standardized bacterial taxonomy based on genome phylogeny substantially revises the tree of life. Nat. Biotechnol. 2018, 36, 996-1004. [CrossRef]

61. Rückert, C.; Albersmeier, A.; Busche, T.; Jaenicke, S.; Winkler, A.; Fri, Ó.H.; Lambert, C.; Badcock, D.; Bernaerts, K.; Anne, J.; et al. Complete genome sequence of Streptomyces lividans TK24. J. Biotechnol. 2015, 199, 21-22. [CrossRef]

62. Guarnieri, M.T.; Levering, J.; Henard, C.A.; Boore, J.L.; Betenbaugh, M.J.; Zengler, K.; Knoshaug, E.P. Genome sequence of the oleaginous green slga, Chlorella vulgaris UTEX 395. Front Bioeng Biotechnol. 2018, 6, 7. [CrossRef]

63. Xu, L.; Sun, C.; Huang, M.; Wu, Y.; Yuan, C.; Dai, W. Marine Genomics Complete genome sequence of Euzebya sp. DY32-46, a marine Actinobacteria isolated from the Pacific Ocean. Mar. Genom. 2018, 44, 65-69. [CrossRef]

64. Abd, H.H.; Baky, E.; El Baroty, G.S.; Mostafa, E.M. Optimization growth of Spirulina (Arthrospira) platensis in photobioreac- tor under varied nitrogen concentration for maximized biomass, carotenoids and lipid contents. Recent Pat. Food Nutr. Agric. 2018, 10, 70-81. [CrossRef]

65. Cuperlovic-culf, M.; Culf, A.S.; Morin, P.J.; Touaibia, M. Application of metabolomics in drug discovery, development and theranostics. Curr. Metab. 2013, 1, 41-57. [CrossRef]

66. Guljamow, A.; Kreische, M.; Ishida, K.; Liaimer, A. crossm high-density cultivation of terrestrial Nostoc strains leads to reprogramming of secondary metabolome. Appl. Environ. Microbiol. 2017, 83, e01510-17. [CrossRef]

67. Cho, D.H.; Choi, J.W.; Kang, Z.; Kim, B.H.; Oh, H.M.; Kim, H.S.; Ramanan, R. Microalgal diversity fosters stable biomass productivity in open ponds treating wastewater. Sci. Rep. 2017, 7, 1979. [CrossRef]

68. Hagihara, R.; Katsuyama, Y.; Sugai, Y.; Onaka, H.; Ohnishi, Y. Novel desferrioxamine derivatives synthesized using the secondary metabolism-specific nitrous acid biosynthetic pathway in Streptomyces davawensis. J. Antibiot. 2018, 71, 911-919. [CrossRef]

69. Jones, M.B.; Nierman, W.C.; Shan, Y.; Frank, B.C.; Spoering, A.; Ling, L.; Peoples, A.; Zullo, A.; Lewis, K.; Nelson, K.E. Reducing the bottleneck in discovery of novel antibiotics. Microb. Ecol. 2016, 73, 658-667. [CrossRef]

70. Setoain, J.; Mart, M.; Tabas-madrid, D.; Sorzano, C.O.S.; Bakker, A.; Gonzalez-couto, E.; Elvira, J.; Pascual-montano, A.; Elmer, P. NFFinder: An online bioinformatics tool for searching similar transcriptomics experiments in the context of drug repositioning. Nucleic Acids Res. 2015, 43, W193-W199. [CrossRef]

71. Heueis, N.; Vockenhuber, M.; Suess, B. Small non-coding RNAs in Streptomycetes. RNA Biol. 2014, 11, 464-469. [CrossRef]

72. Zhang, C. Novel functions for small RNA molecules. Curr. Opin. Mol. Ther. 2009, 11, 641-651.

73. Liu, W.; Shi, Y.; Yao, L.; Zhou, Y.; Ye, B. Prediction and characterization of small non-coding RNAs related to secondary metabolites in Saccharopolyspora erythraea. PLoS ONE 2013, 8, e8067611. [CrossRef] [PubMed]

74. Shah, S.; Xue, Q.; Tang, L.; Carney, J.R.; Betlach, M.; Mcdaniel, R. Cloning, characterization and heterologous expression of a polyketide synthase of oleandomycin and $\mathrm{p}-450$ oxidase involved in the biosynthesis the antibiotic encoding the 6-deoxyerythronolide. J. Antibiot. (Tokyo) 2000, 53, 502-508. [CrossRef] [PubMed]

75. Peano, C.; Talà, A.; Corti, G.; Pasanisi, D.; Durante, M.; Mita, G.; Bicciato, S. Comparative genomics and transcriptional profiles of Saccharopolyspora erythraea NRRL 2338 and a classically improved erythromycin over-producing strain. Microb. Cell Fact. 2012, 11, 32. [CrossRef] [PubMed]

76. Hou, S.; Brenes-álvarez, M.; Reimann, V.; Omer, S.; Backofen, R.; Muro-pastor, A.M.; Hess, W.R.; Backofen, R.; Muro-pastor, A.M.; Crispr-cas, W.R.H. CRISPR-Cas systems in multicellular cyanobacteria. RNA Biol. 2018, 16, 518-529. [CrossRef]

77. Tong, Y.; Charusanti, P.; Zhang, L.; Weber, T.; Lee, S.Y. CRISPR-Cas9 based engineering of actinomycetal genomes. ACS Synth. Biol. 2015, 4, 1020-1029. [CrossRef] 
78. Keun, S.; Hwan, G.; Seong, W.; Kim, H.; Kim, S.; Lee, D.; Lee, S. CRISPR interference-guided balancing of a biosynthetic mevalonate pathway increases terpenoid production. Metab. Eng. 2016, 38, 228-240.

79. Crawley, A.B.; Henriksen, J.R. CRISPRdisco: An automated pipeline for the discovery and analysis of CRISPR-Cas systems. CRIAPR J. 2018, 1, 171-181. [CrossRef]

80. Jhanker, Y.M.; Kadir, M.F.; Khan, R.I.; Hasan, R. Proteomics in drug discovery. J. Appl. Pharm. Sci. 2012, 2, 1-12. [CrossRef]

81. Lindsay, M.A. Target discovery. Nat. Rev. Drug Discov. 2003, 2, 831-838. [CrossRef]

82. Scheepstra, M.; Hekking, K.F.W.; Van Hijfte, L.; Folmer, R.H.A. Bivalent ligands for protein degradation in drug discovery. Comput. Struct. Biotechnol. J. 2019, 17, 160-176. [CrossRef]

83. Frantzi, M.; Latosinska, A.; Mischak, H. Proteomics in drug development: The dawn of a new era? Proteom. Clin. Appl. 2019, 13, e1800087. [CrossRef] [PubMed]

84. Ctortecka, C.; Palve, V.; Kuenzi, B.M.; Fang, B.; Sumi, N.J.; Izumi, V.; Novakova, S.; Kinose, F.; Rix, L.L.R.; Haura, E.B.; et al. Functional Proteomics and deep network interrogation reveal a complex mechanism of action of midostaurin in lung cancer cells. Mol. Cell Proteom. 2018, 17, 2434-2447. [CrossRef] [PubMed]

85. Svozil, J.; Baerenfaller, K. A Cautionary tale on the inclusion of variable posttranslational modifications in database-dependent searches of mass spectrometry data. Methos Enzymol. 2017, 586, 433-452. [CrossRef]

86. Adibekian, A.; Stallforth, P.; Hecht, M.; Werz, D.B.; Seeberger, P.H. Comparative bioinformatics analysis of the mammalian and bacterial glycomes. Chem. Sci. 2011, 2, 337-344. [CrossRef]

87. Buck, C.B.; Thompson, C.D.; Roberts, J.N.; Müller, M.; Lowy, D.R.; Schiller, J.T. Carrageenan is a potent inhibitor of papillomavirus infection. PLoS Pathog. 2006, 2, e69. [CrossRef]

88. Aoki-Kinoshita, K.F. Using glycome databases for drug discovery. Expert Opin. Drug Discov. 2008, 3, 877-890. [CrossRef]

89. Furmaniak, M.A.; Misztak, A.E.; Franczuk, M.D.; Wilmotte, A.; Waleron, M.; Waleron, K.F. Edible cyanobacterial genus Arthrospira: Actual state of the art in cultivation methods, genetics, and application in medicine. Front. Microbiol. 2017, 8, 541. [CrossRef]

90. Santoyo, S.; Jaime, L.; Plaza, M.; Herrero, M.; Rodriguez-Meizoso, I.; Ibañez, E.; Reglero, G. Antiviral compounds obtained from microalgae commonly used as carotenoid sources. J. Appl. Phycol. 2012, 24, 731-741. [CrossRef]

91. Okuyama, H.; Tominaga, A.; Fukuoka, S.; Taguchi, T.; Kusumoto, Y.; Ono, S. Spirulina lipopolysaccharides inhibit tumor growth in a Toll-like receptor 4-dependent manner by altering the cytokine milieu from interleukin-17/interleukin-23 to interferon- $\gamma$. Oncol. Rep. 2017, 37, 684-694. [CrossRef]

92. Ahmadi, A.; Zorofchian Moghadamtousi, S.; Abubakar, S.; Zandi, K. Antiviral potential of algae polysaccharides isolated from marine sources: A review. BioMed Res. Int. 2015, 2015, e825203. [CrossRef]

93. Haubrich, B.A. Microbial Sterolomics as a Chemical Biology Tool. Molecules 2018, 6, 23. [CrossRef] [PubMed]

94. Costa, E.; Silva, J.; Mendonça, S.H.; Abreu, M.H.; Domingues, M.R. Lipidomic approaches towards deciphering glycolipids from microalgae as a reservoir of bioactive lipids. Mar. Drugs 2016, 14, 101. [CrossRef]

95. Kohli, G.S.; John, U.; Van Dolah, F.M.; Murray, S.A. Evolutionary distinctiveness of fatty acid and polyketide synthesis in eukaryotes. ISME J. 2016, 10, 1877-1890. [CrossRef] [PubMed]

96. Boukhris, S.; Athmouni, K.; Hamza-mnif, I.; Siala-elleuch, R.; Ayadi, H.; Nasri, M.; Sellami-kamoun, A. The Potential of a brown microalga cultivated in high salt medium for the production of high-value compounds. BioMed Res. Int. 2017, 2017, e4018562. [CrossRef] [PubMed]

97. Vaz, B.; da, S.; Moreira, J.B.; de Morais, M.G.; Costa, J.A.V. Microalgae as a new source of bioactive compounds in food supplements. Curr. Opin. Food Sci. 2016, 7, 73-77. [CrossRef]

98. Villarruel-López, A.; Ascencio, F.; Nuño, K. Microalgae, a Potential Natural Functional Food Source-A Review. Pol. J. Food Nutr. Sci. 2017, 67, 251-263. [CrossRef]

99. Maciel, E.; Leal, M.C.; Lillebø, A.I.; Domingues, P.; Domingues, M.R.; Calado, R. Bioprospecting of marine macrophytes using ms-based lipidomics as a new approach. Mar Drugs 2016, 14, 49. [CrossRef] [PubMed]

100. Deshnium, P.; Paithoonrangsarid, K.; Suphatrakul, A.; Meesapyodsuk, D.; Tanticharoen, M.; Cheevadhanarak, S. Temperature-independent and -dependent expression of desaturase genes in filamentous cyanobacterium Spirulina platensis strain C1 (Arthrospira sp. PCC 9438). FEMS Microbiol. Lett. 2000, 184, 207-213. [CrossRef] 
101. Stonik, V.A.; Stonik, I.V. Sterol and sphingoid glycoconjugates from microalgae. Mar Drugs 2018, 16, 554. [CrossRef]

102. Lauritano, C.; Ferrante, M.I.; Rogato, A. Marine Natural Products from Microalgae. An Omics Overview. Mar. Drugs 2019, 17, 269. [CrossRef]

103. Zeng, C.; Wen, B.; Hou, G.; Lei, L.; Mei, Z.; Jia, X.; Chen, X.; Zhu, W.; Li, J.; Kuang, Y.; et al. Lipidomics profiling reveals the role of glycerophospholipid metabolism in psoriasis. Gigascience 2017, 6, 1-11. [CrossRef] [PubMed]

104. Manzo, E.; Cutignano, A.; Pagano, D.; Gallo, C.; Barra, G.; Nuzzo, G.; Sansone, C.; Ianora, A.; Urbanek, K.; Fenoglio, D.; et al. A new marine-derived sulfoglycolipid triggers dendritic cell activation and immune adjuvant response. Sci. Rep. 2017, 7, e6286. [CrossRef] [PubMed]

105. Morgese, M.G.; Mhillaj, E.; Francavilla, M.; Bove, M.; Morgano, L.; Tucci, P.; Trabace, L.; Schiavone, S. Chlorella sorokiniana Extract Improves Short-Term Memory in Rats. Molecues 2016, 21, 1311. [CrossRef]

106. Blondeau, N.; Lipsky, R.H.; Bourourou, M.; Duncan, M.W.; Gorelick, P.B.; Marini, A.M. Alpha-Linolenic Acid: An Omega-3 Fatty Acid with Neuroprotective Properties-Ready for Use in the Stroke Clinic? Biomed Res Int. 2015, 2015, 519830. [CrossRef] [PubMed]

107. Salvador-reyes, L.A.; Luesch, H. Biological targets and mechanisms of action of natural products from marine cyanobacteria. Nat. Prod. Rep. 2015, 32, 478-503. [CrossRef]

108. Matthews, H.; Hanison, J.; Nirmalan, N. “Omics”-Informed drug and biomarker discovery: Opportunities, challenges and future perspectives. Proteomics 2016, 4, 28. [CrossRef]

109. Tuyiringire, N.; Tusubira, D.; Munyampundu, J.P.; Tolo, C.U.; Muvunyi, C.M.; Ogwang, P.E. Application of metabolomics to drug discovery and understanding the mechanisms of action of medicinal plants with anti-tuberculosis activity. Clin. Transl. Med. 2018, 7, 29. [CrossRef] [PubMed]

110. Wishart, D.S. Applications of metabolomics in drug discovery and development. Drugs RD 2008, 9, 307-322. [CrossRef]

111. Rabinowitz, J.D.; Purdy, J.G.; Vastag, L.; Shenk, T.; Koyuncu, E. Metabolomics in drug target discovery. Cold Spring Harb. Symp. Quant. Biol. 2011, 76, 235-246. [CrossRef]

112. Culf, A.S. Applied metabolomics in drug discovery. Expert Opin Drug Discov. 2016, 11, 759-770. [CrossRef]

113. Puddick, J.; Prinsep, M.R. MALDI-TOF mass spectrometry of cyanobacteria: A global approach to the discovery of novel secondary metabolites. Chem NZ 2008, 72, 68-71.

114. Rai, V.; Muthuraj, M.; Gandhi, M.N.; Das, D. Real-time iTRAQ-based proteome profiling revealed the central metabolism involved in nitrogen starvation induced lipid accumulation in microalgae. Nat. Publ. Gr. 2017, 7, e45732. [CrossRef] [PubMed]

115. Salv, F.; Jae, D.; Karlsson, A.; Id, F.B.; Kristiansson, E.; Moore, E.R.B. Proteotyping bacteria: Characterization, differentiation and identification of pneumococcus and other species within the Mitis Group of the genus Streptococcus by tandem mass spectrometry proteomics. PLoS ONE 2018, 13, e0208804. [CrossRef]

116. Fenselau, C. Rapid characterizaion of microorganisms by mass spectrometry. What can be learned and how? J. Am. Soc. Mass Spectrom. 2013, 24, 1161-1166. [CrossRef] [PubMed]

117. Marvin, L.F.; Roberts, M.A.; Fay, L.B. Matrix-assisted laser desorption/ionization time-of-flight mass spectrometry in clinical chemistry. Clin. Chim. Acta 2003, 337, 11-21. [CrossRef]

118. El-Aneed, A.; Cohen, A.; Banoub, J. Mass spectrometry, review of the basics: Electrospray, MALDI, and commonly used mass analyzers. Appl. Spectrosc. Rev. 2009, 44, 210-230. [CrossRef]

119. Wang, H.; Yang, Y.; Chen, W.; Ding, L.; Li, P.; Zhao, X.; Wang, X.; Li, A.; Bao, Q. Identification of differentially expressed proteins of Arthrospira (Spirulina) plantensis-YZ under salt-stress conditions by proteomics and qRT-PCR analysis. Proteome Sci. 2013, 11, 6. [CrossRef]

120. Jahoda, E.; Raus, M.; Has, P. Intact cell MALDI-TOF mass spectrometric analysis of Chroococcidiopsis cyanobacteria for classification purposes and identification of possible marker proteins. PLoS ONE 2018, 13, e0208275. [CrossRef]

121. Sun, L.; Jiang, W.; Sato, H.; Kawachi, M.; Lu, X. Rapid classification and identification of microcystis aeruginosa strains using MALDI-TOF MS and polygenetic analysis. PLoS ONE 2016, 11, e0170637. [CrossRef]

122. Johnston, S.; Rees, E.; Thomas, I.; Jones, C.; Reid, M.; Davies, A.P.; Harris, L.G.; Mack, D.; Johnston, S.; Rees, E.; et al. Comparison of bacterial identification by MALDI- TOF mass spectrometry and conventional diagnostic microbiology methods. Br. J. Biomed. 2018, 4845, 47-55. 
123. Esquenazi, E.; Coates, C.; Simmons, L.; Gonzalez, D.; Gerwick, W.H.; Dorrestein, P.C. Visualizing the spatial distribution of secondary metabolites produced by marine cyanobacteria and sponges via MALDI-TOF imaging. Mol. Biosyst. Mol. Biosyst. 2008, 4, 562-570. [CrossRef] [PubMed]

124. Dashti, Y.; Grkovic, T.; Abdelmohsen, U.R.; Hentschel, U.; Quinn, R.J. Actinomycete metabolome induction/suppression with N-acetylglucosamine. J. Nat. Prod. 2017, 80, 828-836. [CrossRef] [PubMed]

125. Gautam, K.; Tripathi, J.K.; Pareek, A.; Sharma, D.K. Growth and secretome analysis of possible synergistic interaction between green algae and cyanobacteria. J. Biosci. Bioeng. 2018, 127, 213-221. [CrossRef] [PubMed]

126. Li, J.; Neubauer, P. Escherichia coli as a cell factory for heterologous production of nonribosomal peptides and polyketides. New Biotechnol. 2014, 31, 579-585. [CrossRef]

127. Huo, L.; Hug, J.J.; Fu, C.; Bian, X.; Zhang, Y.; Müller, R. Natural Product Reports Heterologous expression of bacterial natural product biosynthetic pathways. Nat. Prod. Rep. 2019, 36, 1412-1436. [CrossRef]

128. Said, J.S.; Trybala, E.; Görander, S.; Ekblad, M.; Liljeqvist, J.Å.; Jennische, E.; Lange, S.; Bergström, T. The cholestanol-conjugated sulfated oligosaccharide PG545 disrupts the lipid envelope of herpes simplex virus particles. Antimicrob. Agents Chemother. 2016, 60, 1049-1057. [CrossRef]

129. Yang, F.; Tang, Q.; Zhong, X.; Bai, Y.; Chen, T.; Zhang, Y.; Li, Y.; Zheng, W. Surface decoration by Spirulina polysaccharide enhances the cellular uptake and anticancer efficacy of selenium nanoparticles. Int. J. Nanomed. 2012, 7, 835-844. [CrossRef]

130. Blin, K.; Medema, M.H.; Kottmann, R.; Lee, S.Y.; Weber, T. The antiSMASH database, a comprehensive database of microbial secondary metabolite biosynthetic gene clusters. Nucleic Acids Res. 2016, 45, D555-D559. [CrossRef]

131. Medema, M.H.; Blin, K.; Cimermancic, P.; De Jager, V.; Zakrzewski, P.; Fischbach, M.A.; Weber, T.; Takano, E.; Breitling, R. AntiSMASH: Rapid identification, annotation and analysis of secondary metabolite biosynthesis gene clusters in bacterial and fungal genome sequences. Nucleic Acids Res. 2011, 39, W339-W346. [CrossRef]

132. Schorn, M.; Zettler, J.; Noel, J.P.; Dorrestein, P.C.; Moore, B.S.; Kaysser, L. The genetic basis for the biosynthesis of the pharmaceutically important class of epoxyketone proteasome inhibitors. ACS Chem. Biol. 2014, 9, 301-309. [CrossRef]

133. Sun, J.; Su, Y.; Wang, T. Expression, purification and identification of CtCVNH, a novel anti-HIV ( Human Immunodeficiency Virus ) protein from Ceratopteris thalictroides. Int. J. Mol. Sci. 2013, 14, 7506-7514. [CrossRef] [PubMed]

134. Hussain, A.; Rather, M.A.; Dar, M.S.; Aga, M.A.; Ahmad, N.; Manzoor, A.; Qayum, A.; Shah, A.; Mushtaq, S.; Ahmad, Z.; et al. Novel bioactive molecules from Lentzea violacea strain AS 08 using one strain-many compounds (OSMAC) approach. Bioorg. Med. Chem. Lett. 2017, 27, 2579-2582. [CrossRef] [PubMed]

135. Scherlach, K.; Hertweck, C. Triggering cryptic natural product biosynthesis in microorganisms. Org. Biomol. Chem. 2009, 7, 1753-1760. [CrossRef] [PubMed]

136. Bode, H.B.; Bethe, B.; $\mathrm{H}^{\wedge} \mathrm{fs}, \mathrm{R} . ; \mathrm{Zeeck}$, A. Big effects from small changes: Possible ways to explore nature's chemical diversity. Chembiochem 2002, 3, 619-627. [CrossRef]

137. Kçnig, C.C.; Scherlach, K.; Schroeckh, V.; Horn, F.; Nietzsche, S.; Brakhage, A.A.; Hertweck, C. Bacterium induces cryptic meroterpenoid pathway in the pathogenic fungus Aspergillus fumigatus. ChemBioChem 2013, 14, 938-942. [CrossRef]

138. Abdelwahab, M.F.; Kurtán, T.; Mándi, A.; Müller, W.E.G.; Fouad, M.A.; Kamel, M.S.; Liu, Z.; Ebrahim, W.; Daletos, G.; Proksch, P. Induced secondary metabolites from the endophytic fungus Aspergillus versicolor through bacterial co-culture and OSMAC approaches. Tetrahedron Lett. 2018, 59, 2647-2652. [CrossRef]

139. Pan, R.; Bai, X.; Chen, J.; Zhang, H.; Wang, H.; Aon, J.C. Exploring structural diversity of microbe secondary metabolites using OSMAC strategy: A literature review. Front. Microbiol. 2019, 10, 294. [CrossRef]

140. Romano, S. Extending the "one strain many compounds" (OSMAC) principle to marine microorganisms. Mar. Drugs 2018, 16, 244. [CrossRef]

141. Eckelmann, D.; Spiteller, M.; Kusari, S. Spatial-temporal profiling of prodiginines and serratamolides produced by endophytic Serratia marcescens harbored in Maytenus serrata. Sci. Rep. 2018, 8, 5283. [CrossRef]

142. Kusari, S.; Lamshoeft, M.; Kusari, P.; Gottfried, S.; Zuehlke, S.; Louven, K.; Hentschel, U.; Kayser, O.; Spiteller, M. Endophytes are hidden producers of maytansine in Putterlickia roots. J. Nat. Prod. 2014, 77, 2577-2584. [CrossRef] 
143. Wang, W.L.; Xu, S.Y.; Ren, Z.G.; Tao, L.; Jiang, J.W.; Zheng, S. Application of metagenomics in the human gut microbiome. World J. Gastroenterol. 2015, 21, 803-814. [CrossRef] [PubMed]

144. Gadea, A.; Le Lamer, A.; Le Gall, S.; Jonard, C.; Ferron, S.; Catheline, D.; Ertz, D.; Le Pogam, P.; Boustie, J.; Lohézic, F.; et al. Intrathalline metabolite profiles in the lichen Argopsis friesiana shape gastropod grazing patterns. J. Chem. Ecol. 2018, 44, 471-482. [CrossRef] [PubMed]

145. De Oliveira, L.S.; Gregoracci, G.B.; Gueiros, G.; Silva, Z.; Salgado, L.T.; Filho, G.A.; Alves-ferreira, M.; Pereira, R.C.; Thompson, F.L. Transcriptomic analysis of the red seaweed Laurencia dendroidea (Florideophyceae, Rhodophyta) and its microbiome. BMC Genom. 2012, 13, 487. [CrossRef] [PubMed]

146. Segev, E.; Wyche, T.P.; Kim, K.H.; Ellebrandt, C.; Vlamakis, H.; Barteneva, N.; Paulson, J.N.; Chai, L.; Clardy, J.; Kolter, R. Dynamic metabolic exchange governs a marine algal-bacterial interaction. eLife 2016, 5, e17473. [CrossRef] [PubMed]

147. Aiyar, P.; Schaeme, D.; García-Altares, M.; Carrasco Flores, D.; Dathe, H.; Hertweck, C.; Sasso, S.; Mittag, M. Antagonistic bacteria disrupt calcium homeostasis and immobilize algal cells. Nat. Commun. 2017, 8, 1756. [CrossRef]

148. Salim, A.; Chin, Y.; Kinghorn, A. Bioactive Molecules and Medicinal Plants; Ramawat, K., Merillon, J., Eds.; Springer: Berlin/Heidelberg, Germany, 2008; pp. 1-24. [CrossRef]

149. Shoemaker, R.H. The NCI60 human tumour cell line anticancer drug screen. Nat. Rev. Cancer 2006, 6, 813-823. [CrossRef]

150. Cong, F.; Cheung, A.K.; Huang, S.A. Chemical Genetics-Based Target Identification in Drug Discovery. Annu. Rev. Pharmacol. 2012, 52, 57-78. [CrossRef]

151. Sundarrajan, S.; Lulu, S.; Arumugam, M. Computational evaluation of phytocompounds for combating drug resistant tuberculosis by multi-targeted therapy. J. Mol. Model 2015, 21, 247. [CrossRef]

152. Pereira, F.; Aires-de-Sousa, J. Computational methodologies in the exploration of marine natural product leads. Mar. Drugs 2018, 16, 236. [CrossRef]

153. Paiva, F.C.R.; Ferreira, G.M.; Trossini, G.H.G.; Pinto, E. Identification, In vitro testing and molecular docking studies of microginins' mechanism of angiotensin-converting enzyme inhibition. Molecules 2017, 22, 1884. [CrossRef]

154. Verma, E.; Mishra, A.K.; Singh, A.K.; Singh, V.K. Structural elucidation and molecular docking of a novel antibiotic compound from cyanobacterium Nostoc MGL001. Front. Microbiol. 2016, 7, 1899. [CrossRef]

155. Gkelis, S.; Panou, M.; Konstantinou, D.; Apostolidis, P.; Kasampali, A.; Papadimitriou, S.; Kati, D.; Di Lorenzo, G.M.; Ioakeim, S.; Zervou, S.K.; et al. Diversity, cyanotoxin production, and bioactivities of cyanobacteria isolated from freshwaters of greece. Toxins (Basel) 2019, 11, 436. [CrossRef]

156. Mudimu, O.; Rybalka, N.; Bauersachs, T.; Born, J.; Friedl, T.; Schulz, R. Biotechnological screening of microalgal and cyanobacterial strains for biogas production and antibacterial and antifungal effects. Metabolites 2014, 4, 373-393. [CrossRef] [PubMed]

157. Lauritano, C.; Andersen, J.H.; Hansen, E.; Albrigtsen, M.; Escalera, L.; Esposito, F.; Helland, K.; Hanssen, K.Ø.; Romano, G.; Ianora, A. Bioactivity screening of microalgae for antioxidant, anti-inflammatory, anticancer, anti-diabetes, and antibacterial activities. Front. Mar. Sci. 2016, 3, 68. [CrossRef]

158. Koleva, M.N.; Fernandez-ballester, G. In silico approaches for TRP channel modulation. Methods Mol. Biol. 2019, 1987, 187-206. [CrossRef]

159. Rehman, N.U.; Rafiq, K.; Khan, A.; Halim, S.A.; Ali, L.; Al-Saady, N.; Al-Balushi, A.H.; Al-Busaidi, H.K.; Al-Harrasi, A. $\alpha$-Glucosidase inhibition and molecular docking studies of natural brominated metabolites from marine macro brown alga Dictyopteris hoytii. Mar. Drugs 2019, 17, 666. [CrossRef] [PubMed]

160. Joshi, S.R.; Standl, E.; Tong, N.; Shah, P.; Kalra, S.; Rathod, R. Therapeutic potential of $\alpha$-glucosidase inhibitors in type 2 diabetes mellitus: An evidence-based review. Expert Opin. Pharm. 2015, 16, 1959-1981. [CrossRef] [PubMed]

161. Chapel, C.; Garcia, C.; Roingeard, P.; Zitzmann, N.; Dubuisson, J.; Dwek, R.A.; Trépo, C.; Zoulim, F.; Durantel, D. Antiviral effect of $\alpha$-glucosidase inhibitors on viral morphogenesis and binding properties of hepatitis C virus-like particles. J. Gen. Virol. 2006, 87, 861-871. [CrossRef] 
162. Davis, G.D.J.; Vasanthi, A.H.R. QSAR based docking studies of marine algal anticancer compounds as inhibitors of protein kinase B (PKB $\beta)$. Eur. J. Pharm. Sci. 2015, 76, 110-118. [CrossRef]

163. Montone, C.M.; Capriotti, A.L.; Cavaliere, C.; La Barbera, G.; Piovesana, S.; Chiozzi, R.Z.; Laganà, A. Peptidomic strategy for purification and identification of potential ACE-inhibitory and antioxidant peptides in Tetradesmus obliquus microalgae. Anal. Bioanal. Chem. 2018, 410, 3573-3586. [CrossRef]

(C) 2020 by the authors. Licensee MDPI, Basel, Switzerland. This article is an open access article distributed under the terms and conditions of the Creative Commons Attribution (CC BY) license (http://creativecommons.org/licenses/by/4.0/). 